\title{
The Two Facets of Collaboration: Cooperation and Coordination in Strategic Alliances
}

\section{Citation}

Gulati, Ranjay, Franz Wohlgezogen, and Pavel Zhelyazkov. "The Two Facets of Collaboration: Cooperation and Coordination in Strategic Alliances." Academy of Management Annals 6 (2012): 531-583.

\section{Permanent link}

http://nrs.harvard.edu/urn-3:HUL.InstRepos:10996795

\section{Terms of Use}

This article was downloaded from Harvard University's DASH repository, and is made available under the terms and conditions applicable to Open Access Policy Articles, as set forth at http:// nrs.harvard.edu/urn-3:HUL.InstRepos:dash.current.terms-of-use\#OAP

\section{Share Your Story}

The Harvard community has made this article openly available.

Please share how this access benefits you. Submit a story.

Accessibility 


\title{
THE TWO FACETS OF COLLABORATION: COOPERATION AND COORDINATION IN STRATEGIC ALLIANCES
}

\author{
Ranjay Gulati* \\ Harvard Business School \\ Franz Wohlgezogen* \\ Kellogg School of Management
}

Pavel Zhelyazkov*

Harvard Business School

* We would like to thank Beth Bechky, Heidi Gardner, Venkat Kuppuswamy, Phanish Puranam, Marlo Raveendran, Luciana Silvestri, Christopher Steele, Sameer Srivastava, Maxim Sytch, Bart Vanneste, Andras Tilcsik and Aks Zaheer for their helpful comments on earlier drafts of this paper, as well as Royston Greenwood for his generous support throughout the project. A previous version of this paper was presented at the 2011 Academy of Management meeting in San Antonio, TX. Authors contributed equally. 


\begin{abstract}
This paper unpacks two underspecified facets of collaboration: cooperation and coordination. Prior research has emphasized cooperation, and specifically the partners' commitment and alignment of interests, as the key determinant of collaborative success. Scholars have paid less attention to the critical role of coordination-the effective alignment and adjustment of the partners' actions. To redress this imbalance, we conceptually disentangle cooperation and coordination in the context of interorganizational collaboration, and examine how the two phenomena play out in the partner selection, design, and post-formation stages of an alliance's life cycle. As we demonstrate, a coordination perspective helps resolve some empirical puzzles, but it also represents a challenge to received wisdom grounded in the salience of cooperation. To stimulate future research, we discuss alternative conceptualizations of the relationship between cooperation and coordination, and elaborate on their normative implications.
\end{abstract}




\section{INTRODUCTION}

Inter-organizational collaboration can be extraordinarily complex and risky. Some studies report extremely high failure rates for collaborative endeavors, such as strategic alliances and joint ventures, ${ }^{1}$ often well in excess of 50 percent (Kale, Dyer, \& Singh, 2002; Kale \& Singh, 2009; Lunnan \& Haugland, 2008). These discouraging statistics, and colorful folklore about high-profile alliance failures, feed a prevailing discourse that highlights the hazards of collaboration (Bamford, Gomes-Casseres, \& Robinson, 2004; Dyer, Kale, \& Singh, 2001).

What accounts for the high failure rate of inter-organizational collaborations? The overwhelming majority of sociological and economic studies assert that the partners' failure to cooperate leads to the ultimate demise of such ties, stemming from the misaligned incentives of self-interested agents. At best, conflicting interests can cause diminished commitment that gradually withers the relationship (Doz, 1996); at worst, they can lead to opportunism, or the pursuit of self-interest with no regard for unenforceable commitments or moral obligations (Williamson, 1985). Multiple perspectives, including transaction-cost economics (Kogut, 1988; Oxley, 1997; Sampson, 2004), game theory (Arend \& Seale, 2005; Parkhe, 1993), the social-structural perspective (Gulati, 1995a; Gulati, 1995b; Robinson \& Stuart, 2007), and trust-based perspectives (Ring \& Van de Ven, 1994; Uzzi, 1997; Zaheer, McEvily, \& Perrone, 1998), have been employed to explain when, why, and to what effect cooperation problems emerge in alliances. The normative implications of such research consist primarily of

${ }^{1}$ Because the majority of inter-organizational collaborations over the past decades have taken the form of a range of alliances that include joint ventures (Gulati, 1995a), we will refer to the two concepts interchangeably. 
anticipating and preventing lying, stealing, and cheating among partners, and of sustaining partners' commitment, containing hostilities, and minimizing shirking behavior. Thus political skills, legal expertise, diplomacy, and psychological acumen seem to be required if alliance managers are to ensure the success of their partnerships.

But there is an alternative view of inter-organizational collaboration, one that considers coordination among partners as integral to collaborative efforts (Gulati, 2007a, 2010; Gulati, Lawrence, \& Puranam, 2005; Gulati \& Singh, 1998). This “coordination perspective" focuses less on preventing opportunistic behavior and sustaining commitment than on the mechanics of bringing together partners' contributions. ${ }^{2}$ The implicit assumption here is that, even in a situation of perfect alignment of interests, partners still need to divide labor and to coordinate effectively to complete their joint and individual tasks. As a result, the focus shifts to creating structures, institutions, and relationships that enable partners to work together across boundaries. The coordination perspective emphasizes organization design, communication, and process management as requisite skills of alliance managers.

Some pockets of research on inter-organizational collaboration-such as those that study the antecedents and consequences of contracting and post-formation dynamics - have begun acknowledging the importance of both cooperation and coordination, but progress is uneven at best; some important streams of research on

2 The distinction between "cooperation" and "coordination" has been previously used to delineate the underlying facets of collaboration within organizations (e.g. Gulati, 2007b; Gulati, 2010), and across organizational boundaries (e.g. Rogers \& Whetten 1982). Here we apply and extend these notions to develop an analytic framework for the dynamics of inter-organizational collaboration. 
alliances remain single-mindedly focused on the cooperation perspective. We aim to redress this imbalance by presenting a balanced view of cooperation and coordination as two indispensable facets of inter-organizational collaboration. We begin by outlining the cooperation and coordination perspectives, unpacking the concepts and highlighting some of their confounding elements. Second, we specify the roles of cooperation and coordination during three distinct phases of alliances: partner selection, alliance design, and post-formation dynamics (Gulati, 1998); within each phase, we review prior research grounded in either perspective. We also discuss how a combined perspective could provide a more comprehensive and nuanced account of partnerships, resolve some puzzles intractable from the cooperation perspective alone, and open up new avenues for research. Finally, we examine the theoretical foundations and normative implications of the different ways in which cooperation and coordination relate to each other, as well as to the performance of the collaboration. We conclude with a discussion of research questions that draw on both sets of issues. 


\section{CONCEPTUAL FOUNDATIONS}

\section{The Cooperation Perspective}

We define inter-organizational cooperation as joint pursuit of agreed-on goal(s) in a manner corresponding to a shared understanding about contributions and payoffs. ${ }^{3}$

Cooperation, in this view, is a behavioral outcome of variable quality-inter-

organizational relations can range from highly cooperative to highly uncooperative- that relies on partners' agreement about the provision and appropriation of resources for the collaborative effort (see Table 1). Organizations negotiate what they are willing to contribute (time, resources, market access, etc.) to get what they want (new IP, more efficiency, enhanced legitimacy, etc.) from the alliance. The agreement that they forge on these inputs and outputs describes the intended "extent of cooperation," or the intended scope of the relationship. That scope can range from narrowly defined and clearly budgeted short-term initiatives (such as a co-promotion arrangement) to broad and openended long-term engagement (such as technology/IP sharing partnerships). Whether narrow or broad in scope, organizations typically engage in cooperation to share investment risk or to pursue a variety of operational, commercial, technological, or

${ }^{3}$ Unless otherwise specified, we assume organizational actors rather than specific individuals involved to be the decision makers in an alliance. A minimum level of cooperation among organizational actors (e.g., exchange of information, arranging logistics) has long been recognized as fundamental to any market transaction, even an arm's-length one (Smith, [1776] 1979; Tuomela, 2000). Our focus here, like that of most contemporary management research on inter-organizational cooperation, is narrower: we are examining enduring close ties, especially alliances of various forms including joint ventures, which involve deeper levels of mutual engagement, and usually more interdependence and more joint decision making, than do pure-form transactional relationships (Powell, 1990). 
reputational benefits that may be difficult or impossible to attain via transactional relationships (Oliver, 1990).

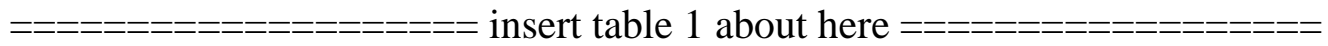

Agreements on inputs and outputs create a particular configuration of resource interdependence (Pfeffer \& Nowak, 1976; Pfeffer \& Salancik, 1978) between partners, since each partner's expected benefits from the relationship depend on others' contributions. The larger the intended extent of cooperation - that is, the more inputs are provided or outputs are expected - the higher the interdependence among partners and the greater the need for a high level of cooperation among them, all else being equal (Gulati \& Sytch, 2007).

Given resource interdependence, the key cooperation concern is that the partners won't behave as agreed with regard to contributions or payoffs. Such deviations constitute cooperation failures: organizations may shirk — contribute less than agreed — or try to claim more benefits than agreed via misappropriation of partner resources or alliance outcomes or via holdup, the exploitation of a superior bargaining position to negotiate more favorable terms. ${ }^{4}$ Cooperation failures lead partners to negatively evaluate the

${ }^{4}$ Alliance research often assumes that partners have a shared understanding of the cooperation agreement, and shared expectations about contributions and claims to outcomes that flow from it. But even detailed formal agreements cannot fully and unequivocally specify expectations (Klein, 1996). Thus partners can have idiosyncratic and shifting understandings of expectations in the partnership, and can subjectively evaluate others' behavior against their understandings of expectations (Ring \& Van de Ven, 1994). Misalignments of partners' subjective perceptions of expectations and behavior can be reconciled during the course of an alliance if there is adequate communication between the partners. Economic game theorists, for example, have examined in detail when and how partners manage to align expectations to achieve cooperative equilibria in what they call "coordination games" (Camerer, 2003; Knez \& 
cooperativeness of particular participating organizations or the entire joint effort, as they question the sincerity of promises regarding contributions and commitment, and the reliability of agreements about the distributions of payoffs (Gulati, Khanna, \& Nohria, 1994). As a result, partners may reduce their investments in the partnership, contributing to its deterioration and ultimately its dissolution. These unanticipated shifts in partners' support of the joint effort, and specifically changes in the level of their contributions and claims to outcomes, have been designated relational risk (Das \& Teng, 2001; Das \& Teng, 1996; Noteboom, 1999).

Causes and remedies of cooperation failures. Cooperation failures are rooted in partners' diverging/misaligned interests. Alliance partners essentially remain independent economic actors, retain control over their own resource-allocation decisions, have different and possibly conflicting strategic objectives (Deeds \& Hill, 1999; Hamel, 1991; Park \& Ungson, 2001), and may be subject to different sets of environmental influences (Koka, Madhavan, \& Prescott, 2006; Koza \& Lewin, 1998; Madhavan, Koka, \& Prescott, 1998). Internal choices or external pressures may lead partners to exhibit different levels of interest in the joint effort, or direct conflict of interest and rivalry in the relationship.

The problems created by misaligned incentives can be exacerbated by opportunism—economic actors' tendency to pursue their self-interest with guile,

Camerer, 1994). Similarly, in the case of alliances, if there is an alignment of expectations, cooperation failure can be avoided. If there is persistent misalignment of expectations among partners, they can lead to conflict, reduced commitment, and partnership dissolution. Unfortunately, the study of the dynamics of partner expectations and behavior during the course of a partnership has not been the subject of extensive prior research. 
irrespective of "gentlemanly agreements" or moral obligations (Williamson, 1985). ${ }^{5}$

There is disagreement between different research traditions on the universality and the detectability of opportunism. Transaction-cost economists typically believe that all transaction partners should be regarded with caution, either because psychological opportunism is universal or because it is an unobservable characteristic of potential partners (Ghoshal \& Moran, 1996; Williamson, 1985). Sociologists and social psychologists are often more optimistic: they suggest that opportunism varies among economic actors and across situations, determined for example by actor's inherent integrity or positive affect toward partners (Mayer, Davis, \& Schoorman, 1995; Schoorman, Mayer, \& Davis, 2007), and that it can be predicted by reputational indicators such as prior direct partnering experiences (Gulati, 1995b; Li \& Rowley, 2002).

Economics, sociology, and social psychology also suggest different remedies for cooperation failures. The economic perspective (especially transaction-cost economics) has emphasized the need for potential partners to assess the characteristics of a planned alliance, of alternative partners, and of the alliance's environment in order to evaluate the likely level of opportunism and to develop effective responses to limit or prevent it, e.g., through partner selection, formal structures, and contractual arrangements as well as ongoing monitoring and control (Luo, 2006; Williamson, 1991). Partners may establish

5 While some alliance cooperation failures are indeed caused by opportunistic behavior - by "lying, cheating and stealing" partners - many can be traced to less extreme forms of behavior, such as partners' gradual loss of interest in the alliance due to diminished expectations of future benefits from it, or due to a strategic reorientation. A broader conception of cooperation therefore takes into account the level of commitment to the relationship rather than merely the presence or absence of opportunism (Ring \& Van de Ven, 1994). 
formal controls and sanctions based on legally enforceable contractual agreements to limit opportunism. A complementary approach is to rely on private sanctions that do not depend on third-party enforcement (unlike, for example, financial penalties), such as a "shadow of the future," the invocation of future interactions and their benefits (Heide \& Miner, 1992; Poppo, Zhou, \& Ryu, 2008); or an “exchange of hostages,” a mutual commitment to the partnership in the form of investments in relationship-specific assets (Ahmadjian \& Oxley, 2006; Williamson, 1983). Fundamentally, economic perspectives on cooperation emphasize individual partners' need for vigilance and ingenuity to detect and effectively respond to threats of opportunistic behavior. ${ }^{6}$

The social-structural perspective suggests alternative remedies to interorganizational cooperation failures informed by sociology. It is based on the notion that economic activity is "shaped, redirected [and] constrained by social context; norms, interpersonal trust, social networks and social organizations are important in the functioning ... of the economy" (Coleman, 1988: S96). The social-structural perspective thus broadens the focus from formal governance and private sanctions in preventing opportunism to the deterrent power of social pressures and reputational mechanisms. For instance, pre-existing direct and indirect social ties can provide information on potential partners' trustworthiness, and the threat of reputational damage provides disincentives to uncooperative behavior such as shirking, holdup, or misappropriation (Gulati \& Gargiulo,

${ }^{6}$ An alternative approach to the threat of opportunism is suggested by the realoptions perspective on alliance management (Folta \& Miller, 2002; Reuer \& Tong, 2005; Seth \& Chi, 2006). Here the emphasis is less on anticipating specific opportunistic behaviors ex ante. Instead, partners design agreements that allow them to resolve risks dynamically by modifying their partnering decisions (e.g., via the exercise of acquisition or termination options). What this perspective shares with the other economic perspectives is a reliance on individual partners' strategic acumen to ensure positive outcomes from cooperation. 
1999). Similarly, organizations may seek out high-status partners not only because their position can serve as a signal of reliability (Cable \& Shane, 1997; Podolny, 1994) but also because reputational damage would be particularly punitive for these actors (Robinson \& Stuart, 2007). In sum, social structure plays an active role in both the exante selection of partners and the ex-post deterrence of opportunistic behavior. Such reputation-based deterrence relies on institutions and norms about reciprocity, equity/fairness, truthfulness, solidarity, and the like in partners' environments (Coleman, 1988; Guler, 2007; Phillips, Turco, \& Zuckerman, 2011). The socially imposed costs of uncooperative behavior need to be sufficiently and reliably high for partners to base their trust on structural cues.

Finally, the trust-based perspective emphasizes social-psychological mechanisms such as positive affect arising from mutual identification or relational attachment between boundary spanners of the partner organizations in avoiding cooperation failures and in promoting stability and equity in alliances (Gulati \& Sytch, 2008; Ingram \& Yue, 2008; Zaheer et al., 1998). In contrast to the economic and s perspectives, which both emphasize legal, private, or social sanctions, the psychological tradition maintains that partners may not behave opportunistically even if they have an incentive and the ability to do so (Schoorman, Mayer, \& Davis, 1996; Schoorman et al., 2007) because opportunism would violate internalized values and principles of behavior and damage their self-image (Barney \& Hansen, 1994).

Ironically, even as critics of the economic perspective have focused on the roles of social structures and dyadic trust, they have implicitly agreed that ensuring cooperation is the primary problem in alliances. But sustained commitment, relationship- 
specific investments, trust, and contractual safeguards against opportunism do not in themselves guarantee an alliance's success. Despite best intentions, partners may find it difficult to efficiently combine the resources they bring to the table, to synchronize their actions, or to realize the planned payoffs.

\section{The Coordination Perspective}

Coordination is broadly understood in the social sciences as the linking, meshing, synchronization, or alignment of actions (Aiken et al., 1975; Okhuysen \& Bechky, 2009). In an inter-organizational context, we define coordination as the deliberate and orderly alignment or adjustment of partners' actions to achieve jointly determined goals. We regard coordination as an outcome that can be characterized by efficiency, the relative cost of designing and operating coordination mechanisms, and by effectiveness, the degree to which coordination efforts actually produce the desired alignment or adjustment of action. Coordination typically involves the specification and operation of information-sharing, decision-making, and feedback mechanisms in the relationship to unify and bring order to partners' efforts, and to combine partners' resources in productive ways. In short: coordination seeks to ensure that partners' efforts "click" and yield the desired outcomes with minimal process losses. The nature of the order around which such efforts are organized, i.e., the specific internal requirements and external pressures that determine the task structure of the partnership, is up to the participants to 
negotiate. ${ }^{7}$ Similarly, partners negotiate how much aligning and how much adjusting each party undertakes (Killing, 1983; Okhuysen \& Bechky, 2009; Rogers \& Whetten, 1982).

A conceptual focus on coordination issues rather than cooperation issues provides a different perspective on alliances: while the cooperation perspective centers attention on partners' level of agreement about goals, the contribution of resources, and the sharing of benefits, the coordination perspective highlights the specific ways that partners devise to implement and operate the relationship — the nuts and bolts of organization and administration. Importantly, coordination challenges are not automatically resolved merely because partners' interests align (Heath \& Staudenmayer, 2000; Kretschmer \& Puranam, 2008). On the contrary, coordination problems require "intelligent, vigorous, persistent and organized effort" (Gulick \& Urwick, 1937: 6). As numerous studies of public agencies and social-service delivery systems have demonstrated (e.g., Litwak \& Hylton, 1962; Rogers \& Whetten, 1982), even partners with the best intentions and wellaligned incentives can turn out to be incompetent administrators of inter-organizational relationships and fail to find workable answers to questions about who will do what by when and how. By failing to plan, or failing to adjust to each other's practices and structures, and by adopting rigid roles, procedures, and interfaces that prevent ad-hoc responses to emerging problems, partners may jeopardize the attainment of alliance goals. All alliances face coordination challenges, since by definition they involve some division of labor and thus some task interdependence among partners. Hence, all alliances

7 This emphasis on negotiation of coordination arrangements is in keeping with recent scholarship that views coordination requirements as equivocal and ambiguous, and assumes many interdependencies to be less than fully technologically determined and thus subject to some social deliberation (de Rond \& Bouchikhi, 2004; Gulati, Raveendran, \& Silvestri, 2012; Raveendran, Puranam, \& Warglien, 2012) and some strategic choice (Dyer, 1996, 1997). 
require some coordination provisions that enable partners to exchange information and engage in joint planning, and that ensure compatible timing and sequencing of actions (Palmer, 1983), productive combination of resources and capabilities (Das \& Teng, 2000), and quick responses to market changes and trends (Uzzi, 1997).

Organizations engage in coordination efforts to manage the task interdependence that can flow from a given division of labor or from the production technologies in use (Raveendran \& Puranam, 2012; Thompson, 1967), and to manage uncertainties arising from internal tasks or the external environment (Bensaou \& Venkatraman, 1995; Clark \& Fujimoto, 1991; Lawrence \& Lorsch, 1967; Van de Ven, Delbecq, \& Koenig, 1976). ${ }^{8}$ Hence, the extent of the coordination attempted by alliance partners - the range of activities, processes, and roles encompassed in their efforts to align and adjust — can vary widely. As a general rule, coordination scholarship has suggested that higher degrees of interdependence, and higher levels of task and environmental uncertainty, require more extensive forms of coordination (see e.g. Argote, 1982; Galbraith, 1977; Thompson, 1967).

Given task interdependencies, and task and environmental uncertainties in an alliance, partners' key coordination-related concerns are, first, whether they can collectively recognize and manage them and, second, whether they can do so efficiently. Greater interdependence and uncertainty in an alliance may increase coordination costs

8 Incidentally, Barnard's research on the role of organizations in managing the division of labor and ensuing coordination (1938) was published shortly after Coase conceptualized organizations as a means to mitigate the transaction costs of exchange (1937). That is, the foundational texts on organizations' coordination and cooperation issues respectively were written around the same time. 
and may also increase the likelihood of coordination failures, ${ }^{9}$ which can be traced either to the flawed design or to flawed implementation of coordination mechanisms. ${ }^{10}$ Coordination failures can take the form of omissions of crucial activities, spatial or temporal misallocation of resources, and incompatibility of activities intended to be complementary. For example, task uncertainties, which constrain partners' ability to predict the outcome of work processes, increase the likelihood of incompatibilities and make precise synchronization of activities more difficult (Varshney \& Oppenheim, 2011). Coordination failures can have significant adverse consequences for the alliance as a whole: they can cause inefficiencies and delays, and may prevent partners from attaining specific alliance goals (Mohr \& Spekman, 1994). Ultimately, coordination failures can lead alliance partners to doubt the feasibility of the joint enterprise and to abandon the effort. To mirror the concept of relational risk, which encompasses unforeseen changes in partners' commitments and claims in the relationship that

${ }^{9}$ Economists use the term coordination failure to denote situations in which economic actors could have achieved better cooperative equilibria had they coordinated their actions (see, e.g. Cooper, 1998). But research on economic coordination failure often focuses on problems that prevent actors from providing resources to a mutually beneficial joint effort (in our terminology, cooperation problems), rather than problems that affect the combination or integration of resources in a joint effort. The organizationtheory conception of coordination failure, on which we base our arguments, concentrates on these combination and integration problems.

10 Flawed design encompasses factors like erroneous task decomposition, misconceived task allocation (such as assigning tasks to agents ill equipped to handle them), and misspecification of coordination mechanisms such as communication interfaces (Puranam, Raveendran, \& Knudsen, 2012; Raveendran \& Puranam, 2012). Failures of implementation can include actors' mistakes while performing assigned tasks and failure to use specified coordination mechanisms properly. 
jeopardize cooperation, we designate the risk of unforeseen coordination costs and of coordination failures as an alliance's operational risk. ${ }^{11}$

Causes of and remedies for coordination failures. Coordination failure stems from the cognitive limitations of those who design and implement coordination mechanisms, from underlying cultural differences, and from the rigidities and immobility of existing structures, processes, and resources. Cognitive limitations, specifically bounded rationality (Simon \& March, 1993), constrain individuals' ability to fully recognize, project, and accommodate the impact of different types and levels of interdependence among tasks, roles and units. Individuals often fail to recognize interdependencies: they tend to apply heuristics that lead them to think too narrowly and crudely about task partitioning and specialization among roles and units, and to underestimate the interrelationships between tasks and resulting coordination needs (Heath \& Staudenmayer, 2000; Puranam et al., 2012). And even when individuals do recognize interdependencies, attention constraints limit the effectiveness of their coordination efforts by restricting their ability to monitor, manage, and respond to a large number of activities or events (Ocasio, 1997). Especially in alliances characterized by multiple or highly diverse partners, the sheer quantity and variety of coordination issues may be too taxing even for highly capable organizers and administrators, and may

11 The task of managing cooperation and coordination, and by extension managing relational and operational risk, may be assigned to different sets of people within the partnering organizations (Argyres \& Mayer, 2007). For example, ensuring cooperation often falls on senior managers (who control resource allocation decisions) and lawyers who oversee the contracts. The design and operation of detailed coordination mechanisms, by contrast, is often the responsibility of lowerlevel employees and managers. 
impede their ability to distinguish between truly critical issues and those that are merely proximate or recent (Park \& Ungson, 2001).

Coordination failures can also be caused by cultural differences between partner organizations. Given unique organizational, industry, or national cultures, the administrators of the alliance may utilize different and potentially incompatible practices (White, 2005). More fundamentally, however, cultural differences also make cognitive differences between these boundary spanners more likely (Berends, Garud, Debackere, \& Weggeman, 2011): they may have different conceptions of required tasks and of the alliance's environment, and may disagree about which task interdependencies and uncertainties are most important, about how much alignment is required or desirable, and about when the right level of alignment has been achieved (Alter \& Hage, 1993: 78; Gerwin, 2004: 246). This scenario suggests that individuals participating in an alliance are likely to experience significantly more equivocality, i.e. overlapping and conflicting views, about key inter-organizational coordination decisions than about intraorganizational coordination decisions (Daft \& Weick, 1984; de Rond \& Bouchikhi, 2004; Thomas \& Trevino, 1993). These disagreements can exacerbate alliance administrators' existing cognitive limits, and cause omissions of critical actions and incompatibility of efforts intended to be complementary.

Lastly, partners' existing organizational structures, routines, and resources may stand in the way of effective inter-organizational coordination. Organizational inertia can hinder coordination efforts even if all coordination-relevant information is available and understood, and even if agreement exists in principle on how to address coordination needs. Partners may, for example, struggle to implement alliance coordination provisions, 
or changes to such provisions, due to resistance from organizational members or external stakeholders (Doz, 1996; Hannan \& Freeman, 1984). Furthermore, resource stickiness may constrain how fast partners can acquire and integrate new tangible or intangible resources, or repurpose existing resources for new purposes (Mishina, Pollock, \& Porac, 2004; Penrose, 1959; Szulanski, 2003). Thus they will be unable to properly respond to plans if they require resources and capabilities that are not readily available. ${ }^{12}$

To suggest ways in which coordination failures can be overcome, the comparatively small literature on alliance coordination draws on a variety of coordination-related research on intra- and inter-organizational coordination (Alter \& Hage, 1993; Grandori \& Soda, 1995; Smith, Carroll, \& Ashford, 1995). For clarity, we organize these influences into three schools of thought: structural, institutional, and relational.

The structural perspective, rooted in early administrative scholarship, suggests that coordination failures can be avoided by means of appropriate organizational and job design. Early administrative scholarship particularly emphasized the capacity of organizational hierarchies - formal, vertical mechanisms of coordination - to facilitate the accomplishment of complex and interdependent tasks by establishing clear authority relations and formalization of organizational activities (Barnard, 1938; Fayol, 1949; Weber, 1974). Joint-venture structures and formal contracts can replicate key elements of hierarchy (Stinchcombe, 1985)—such as standard operating procedures and hierarchical

12 The assumption of organizational inertia has especially important implications for partner selection: because the partners will have a difficult time adapting their organizational structures and resources to the needs of the alliance, it is critical for the long-term evolution of the collaboration to select partners with a high level of fit to the task at hand and to one's own organization's resources. 
controls - that clarify and formalize the division of labor, overcome individuals' bounded rationality and limited span of attention (Gulati \& Singh, 1998), and bridge cultural differences (Vlaar, Van den Bosch, \& Volberda, 2006).

Coordination scholars building on early administrative research were quick to point out, however, that more formalization and stricter authority structures alone are not enough to ensure efficiency or effectiveness of coordination, and that organizational designers need to consider critical internal and external contingencies to select suitable means of coordination (Burns \& Stalker, 1961; Chandler, 1962; Galbraith, 1977; Thompson, 1967; Tushman \& Nadler, 1978). Such a structural contingency approach suggests that partners need to consider the alliance's and partners' technology, information-processing needs, strategy, and exposure to internal or external change when selecting appropriate structures. Of course, the task of designing congruent alliance structures that take into account such a complex set of contingencies may well exceed the cognitive limits of alliance managers.

The institutional school of thought on coordination suggests that coordination failure can be avoided not just by means of formal and explicit rules, but also by means of informal norms and implicit assumptions derived from broad societal institutions (DiMaggio, 1997) or more industry-, profession-, or organization-specific institutions (Bechky, 2003; Cooper, Hinings, Greenwood, \& Brown, 1996; Cooper, Rose, Greenwood, \& Hinings, 2000; Tilcsik, 2010). These cultural influences can inform individuals' perceptions of task interdependencies (Steensma, Marino, Weaver, \& Dickson, 2000) and their interpretation of the level and impact of external uncertainties (Daft \& Weick, 1984). Selznick encouraged organizational leaders to actively pursue the 
development of institutions to "provide the individual with an ordered approach to his day-to-day problems, a way of responding to the world consistently yet involuntarily, in accordance with approved perspectives yet without continuous reference to explicit formalized rules" (Selznick, 1957: 17). Importantly, shared institutions can enable coordination among actors without much direct communication or interaction by providing a basis for conventions (e.g., metrics and measuring systems), implicitly agreed-on meanings (e.g., for technical or administrative jargon), and values (e.g., the importance of reciprocity, information sharing, constructive feedback, etc.) (Chwe, 2001; Reich \& Mankin, 1986). ${ }^{13}$ But developing alliance-specific institutions to bridge partners' cultural differences can be difficult. Traditional organizations can rely on a unifying "normative territory," clear identification, and clear boundaries to support the socialization and homogenization of diverse employees and the internal development of a shared understanding of the organizational tasks and the organizational environment (Kogut \& Zander, 1996). Inter-organizational partnerships, in contrast, often have to contend with employees' dual identification with the parent organization and the partnership, divided authority structures, and transient boundaries (Schreiner, Kale, \& Corsten, 2009).

The relational school of thought suggests that much inter-organizational coordination is accomplished extemporaneously by individuals and groups. It also has

${ }^{13}$ Economic game theorists also consider the role of implicit understandings and conventions in allowing or preventing mutually beneficial equilibria (Sugden, 1995; Van Huyck, Battalio, \& Rankin, 1997; Young, 1993). A frequently invoked simple example is two cars approaching each other from opposite directions on a road. In most countries, convention leads both drivers to steer to the right side of the road from their own perspective, and thus to pass each other rather than colliding. 
long and distinguished intellectual tradition: Gulick (1937) and Chandler (1962) both argued that managers are critical to coordination not because of their faithful adherence to plans and procedures but because of their skill at ad-hoc interventions to improve productivity, eliminate waste, and ensure adequate responses to unforeseen crises. Alliance managers functioning as "active coordinators" interact directly with others to work out interdependencies and uncertainties (Follett, 1949) and to develop ad-hoc or routine responses to them. This emergent process of coordination relies on partners' careful staffing of the alliance (Phillips, 1960), inter-organizational boundary spanners and liaisons (Gittell, 2002; Provan \& Milward, 1995), strong interpersonal relationships among those boundary spanners and liaisons (Ancona \& Caldwell, 1992; Hansen, 1999; Kale, Singh, \& Perlmutter, 2000), and regular opportunities for them to interact within supportive but relatively unstructured communication and decision-making channels (Thomas \& Trevino, 1993). The effectiveness of this approach is constrained, however, by the cognitive limitations of the "active coordinators" and their ability to overcome cultural differences.

Taken together, these three perspectives illustrate the possible scope of alliances' coordination challenges, and the various means that organizations have at their disposal to tackle them. At a basic level, they remind us that even when questions about partners' motivations and commitment have been resolved, other questions remain about exactly how they are to interact to ensure that objectives are accomplished, synergies are achieved, and resources are used efficiently. This fundamental insight shifts our interpretation of alliances: we view them not merely as deals and strategic agreements but also as entities characterized by boards, staffs, task forces, information and decision- 
making processes, databases, facilities, and other material resources, all of which entail practical real-world organizational challenges. 


\title{
III. COOPERATION AND COORDINATION ACROSS THE LIFE CYCLE OF
}

\begin{abstract}
AN ALLIANCE
The conceptual distinction between the cooperation and coordination perspectives can be applied to the study of alliance outcomes over the entire life of an alliance, from inception to termination. But the two perspectives have rarely been applied consistently across the three stages of the alliance life cycle: (1) partner selection, (2) alliance design, and (3) post-formation dynamics (Gulati, 1998). This section builds on prior research to highlight the two perspectives' differing explanations for partners' decisions and behavior in the three stages. We will highlight how the two perspectives jointly facilitate a richer and more nuanced descriptive and normative understanding of collaborative relationships. Finally, we will propose some research directions suggested by a deeper grasp of the coordination problems within alliances.
\end{abstract}

$==================$ insert table 2 about here $====================$

\section{Partner Selection}

Among the questions surrounding the formation of alliances-primarily, why do firms enter into alliances, and when do they do so and with whom? - the question of partner selection has been particularly actively debated over the past two decades. The overarching thrust of the literature has been to focus on the criteria by which firms select their alliance partners or on the factors that shape the propensity of firms to partner with each other. 


\section{The cooperation perspective on partner selection. Firms' forward-looking}

concerns about future cooperation failure often affect their partner selection criteria. As a result, organizations are likely to consider not only prospective partners resource endowments to ensure complementary contributions that promise high payoffs ways (Eisenhardt \& Schoonhoven, 1996; Pfeffer \& Salancik, 1978), but also try to assess their integrity, reputation, and likely commitment to the partnership to reduce the risk of opportunistic behavior. In particular, organizations seek information about prospective partners' past behavior and track records, and assess inducements to cooperation that these partners may be subject to.

These considerations lead to partner selection based on (1) prior direct partnerships, (2) proximity, (3) partner status, or (4) similarity. Preference for familiar partners - partners with whom the organization has allied before — can be attributed to greater knowledge of their motivation and commitment (Gulati, 1995b; Podolny, 1994). Repeat partnerships also restrain opportunism by increasing anticipation of future productive exchanges ("the shadow of the future," in the words of Axelrod, 1984; Heide \& Miner, 1992), and strengthen commitment by fostering trust and affective interpersonal ties between the boundary spanners (Gulati \& Sytch, 2008; Seabright, Levinthal, \& Fichman, 1992). Organizations have also demonstrated preferences for proximate partners - those that share common ties with the focal organization (Chung, Singh, \& Lee, 2000; Gulati \& Gargiulo, 1999; Walker, Kogut, \& Shan, 1997) or are situated in the 
same industry or region (Sorenson \& Stuart, 2008; Trapido, 2007) ${ }^{14}$ —and for high-status partners (Ahuja, 2000; Guler \& Guillen, 2010). Both proximity and status offer informational advantages - it may be easier to assess proximate or high-status partners' reputations - and deter opportunism by threatening damage to uncooperative partners' reputations. Finally, organizations tend toward homophily, or a preference for partners similar to themselves, characterized by positive affect and by the perception of shared fate and alignment of interests that such similarity entails (Ingram \& Yue, 2008). Reduced cooperation concerns may thus explain why shared national origins (Ingram \& Inman, 1996), shared organizational form (Ingram \& McEvily, 2007), and comparable organizational status (Chung et al., 2000; Podolny, 1994) are all important criteria for partner selection.

The coordination perspective on partner selection. The cooperation perspective can explain many of the empirically observed patterns of partner selection, but its account of the criteria that firms consider during the alliance-formation phase is incomplete: at the outset of an alliance, firms may anticipate ex-ante coordination challenges just as they do cooperation challenges, and thus select the partners with whom they expect interorganizational coordination to be most efficient and most likely to succeed. A coordination perspective on alliance formation — still underdeveloped in the literaturesuggests coordination competence and structural and cultural compatibility as important partner-selection criteria.

${ }^{14}$ Preference for partner familiarity and proximity is strongest when the exchange hazards in the transaction are greatest (Meuleman, Lockett, Manigart, \& Wright, 2010; Sorenson \& Stuart, 2008), suggesting that a desire to reduce relational risk is an important motivation for such behavior. 
While little of the prior research on alliances has explicitly discussed anticipated coordination concerns as a factor shaping the choice of partners, a close look at the selection criteria examined in prior research suggests that some of the criteria used may actually be proxies for ex-ante coordination concerns. For instance, organizations that anticipate coordination challenges in an alliance may look for partners that seem generally competent at inter-organizational coordination. Such an assessment can be based on first-hand experience of a partner's coordination competence (e.g., Li \& Rowley, 2002) or on such proxies as extensive alliance experience (Gulati, 1999) or the presence of a dedicated alliance-management function within a prospective partner's organization (Kale et al., 2002; Schreiner et al., 2009).

It is possible that a potential partner's prior experience may be limited to particular types of partners and alliance contexts, and thus inadequate to ensure efficient and effective coordination. To minimize coordination costs and the likelihood of coordination failures, prior research suggests that organizations may seek partners not just for their competence but also compatibility with regard to resources, organizational processes, language, and culture (Mitsuhashi \& Greve, 2009; Nachum, 2010; Stuart, 1998). Such compatibility in a particular joint effort may be difficult to determine with certainty ex ante, but familiarity among partners provides information about each other's cultural and structural makeup (Li \& Rowley, 2002) and equips them to anticipate and bridge remaining incompatibilities (Zollo, Reuer, \& Singh, 2002). Further, partner proximity in the technology, industry, or geographical space can serve as proxies of compatibility: it increases the odds of partners having similar technological standards, organizational structures, knowledge bases, and a shared language, all of which reduce 
equivocality about coordination requirements and the risk of incompatibilities (Stuart, 1998; White, 2005; White \& Lui, 2005).

Given the importance of compatibility, alliances built on the expected synergistic benefits of complementarities_-value-creating differences in partners' resource endowments - can represent a particular coordination challenge. A higher level of complementarity implies a more complex division of labor because the tasks of each actor become more specialized, increasing interdependence and thus the need for greater coordination (Becker \& Murphy, 1992). Dissimilarity of resources can also increase uncertainty, in that partners are more likely to struggle to understand each other's contributions, how best to integrate them, and what outcomes can be expected from integration. As a result, realizing the potential upside of complementarities requires more extensive and higher-quality coordination efforts (Das \& Teng, 2000) or greater ex-ante compatibility between the partners (Dyer \& Singh, 1998). ${ }^{15}$

Discussion. A side-by-side comparison reveals some similarities between the cooperation and coordination perspectives. Specifically, some partner-selection criteria that are typically viewed as motivated by a desire to reduce relational risk — such as familiarity and similarity — may also have coordination-related motivations. For example, greater familiarity can build trust and facilitate cooperation (Gulati, 1995a), but it can

15 Little is known about how firms manage complementarity and compatibility issues in partner selection, and in particular about whether and when tradeoffs are involved. Existing studies suggest a "Goldilocks principle": a preference for partners that are not too similar and not too dissimilar, in terms of resources and capabilities, to ensure synergistic benefits while avoiding excessive coordination costs (Baum, Cowan, \& Jonard, 2010; Mitsuhashi \& Greve, 2009). However, most studies use proxy variables to assess who partners with whom; there have been no field-based efforts to directly study the deliberations over complementarity and compatibility that precede the formation of alliances. 
also facilitate coordination via familiarity with the partner's coordination capabilities and development of relationship-specific coordination routines (Li \& Rowley, 2002; Zollo et al., 2002). Future research employing in-depth field interviews or surveys may help unpack partner-selection rationales and advance our understanding of whether and how organizations balance cooperation and coordination considerations in different contexts (see, for example, Gulati, 1995b).

The coordination perspective also contributes new insights to our understanding of partner selection. It suggests that the ability to coordinate is an important partnerselection criterion, as well as a preference for more experienced and more capable partners. This possibility is at odds with evidence from cooperation-focused studies, suggesting that a focal organization may prefer counterparties with less alliance experience who would be more vulnerable to its own opportunistic behavior (Graebner, 2009). The coordination perspective also emphasizes a partner's internal characteristics (e.g., its structural or cultural makeup) rather than only its relationships or position (e.g., prior collaborations, status, or proximity) to explain partner-selection decisions. While the cooperation perspective considers some internal organizational characteristics that are linked to organizational identity and can trigger in-group/out-group identifications and positive affect (Ingram \& Yue, 2008), the coordination perspective highlights technical characteristics such as resource similarity and knowledge overlap (Mitsuhashi \& Greve, 2009; Stuart, 1998). Finally, the two perspectives differ in their view of partners' resource complementarities: from a cooperation perspective, complementarities are a clear benefit to alliances in that they can increase mutual dependence between partners and thus incentives for cooperation (Gulati \& Sytch, 2007); from a coordination 
perspective, complementarities involve a more complex division of labor and more

extensive coordination, and thus increase coordination costs (Becker \& Murphy, 1992).

\section{Alliance Design}

The study of alliance design examines the determinants of the governance arrangements negotiated by partners at the outset of an alliance. At a high level, those arrangements include the overarching legal structure of the alliance: is it governed purely by contract or does it include any equity components, such as minority investments by either party or the creation of an autonomous company — a joint venture (JV) - in which each participant takes up a stake? At a more granular level, alliance design encompasses contractual specifications (e.g., information-sharing procedures and conditions that would trigger renegotiation of alliance arrangements or penalties) and informal arrangements (e.g., non-contractual agreements and promises about commitments, inter-organizational liaisons, and flexible adjustments in the future).

The cooperation perspective on alliance design. The central argument of the cooperation perspective on alliance design is that firms trade off the perceived cooperation benefits of formal governance arrangements with the higher costs of such measures. Carefully designed contractual features can increase the probability of detecting and penalizing opportunistic behavior (Carson, Madhok, \& Wu, 2006; Parkhe, 1993); ${ }^{16}$ researchers have suggested that equity JVs can align incentives thanks to the

${ }^{16}$ For example, a contract can specify in detail the responsibilities of the parties and penalties for nonconformance, reducing the probability of shirking. It can include contingencies as to when and how the relationship can be terminated, reducing the probability of holdup. Finally, it can impose restrictions-backed up by appropriate penalties - that limit the use of tangible or intangible resources. 
mutual exchange of hostages in the form of equity investments, robust monitoring mechanisms, and a clear mechanism for distributing the gains of collaboration (Hennart, 1988; Kogut, 1988). But crafting such formal structures can be expensive: negotiating, implementing, and enforcing highly detailed contracts involves significant legal costs and managerial attention (Crocker \& Reynolds, 1993), and creating autonomous entities like JVs entails further capital commitments and exit costs (Kogut, 1988; Sampson, 2004). Thus forward-looking firms are likely to take on the expense of formal structures only if there is a high ex-ante risk of cooperation failures. Transaction-cost economists have focused on exchange hazards that increase vulnerability to opportunism; sociologists and organization theorists also consider factors that decrease the threat of opportunism, such as the relationship between the partners and the larger social structures surrounding them.

Certain characteristics of an alliance can increase the likely dangers of cooperation failure, and thus necessitate more formal governance in the form of detailed contracts or hierarchical governance structures. For example, researchers have show that partners' asset specificity is associated with greater contractual protections to mitigate the dangers of holdup (Mellewigt, Madhok, \& Weibel, 2007; Mesquita \& Brush, 2008; Parkhe, 1993). ${ }^{17}$ Greater scope can increase the risk of shirking, thus calling for the alignment of incentives and monitoring mechanisms that JV governance can provide (Oxley, 1997; Oxley \& Sampson, 2004; Sampson, 2004). For the same reason, JVs are often used in situations characterized by risk of misappropriation and knowledge leakage,

${ }^{17}$ For example, such agreements could reduce the need for further renegotiation to adapt to easily foreseen contingencies. Such renegotiations typically allow the partner with the dependence advantage to appropriate more of the gains of exchange (Hamel, 1991). 
e.g., R\&D alliances in industries with poor intellectual-property rights (Gulati, 1995a;

Pisano, 1989).

Sociologists and organization theorists complement this cooperation perspective by examining how social factors can lead to the selection of less formal governance arrangements. In direct extension of the transaction-cost argument, they have argued that accumulated trust and reputational concerns obviate the need for formal governance arrangements by reducing the perceived probability of opportunism and thus lowering the marginal benefits of costly contracts/equity investments (Gulati, 1995a). They have also suggested that excessive contractual formality may erode the accumulation of trust by implying insufficient confidence in others' integrity (Ghoshal \& Moran, 1996) and by denying them opportunities to demonstrate their trustworthiness (Malhotra \& Murnighan, 2002; Molm, Takahashi, \& Peterson, 2000). Thus actors in high-trust relationships may find it counterproductive to select highly formal governance arrangements, irrespective of their financial cost. The empirical research is generally supportive of these arguments. Prior experience, shared nationality (Gulati, 1995a), and structural proximity in the alliance network (Robinson \& Stuart, 2007) all reduce the probability of selecting a jointventure structure. Similarly, contracts tend to be simpler when ex-ante opportunism concerns are less urgent due to partners' observed past behavior (Crocker \& Reynolds, 1993), or good reputations (Banerjee \& Duflo, 2000). However, the prediction that prior partner-specific experience would lead to more complete contracts has had mixed empirical support: some studies have shown that repeat collaborations feature less complete contracts (Banerjee \& Duflo, 2000; Corts \& Singh, 2004; Kalnins \& Mayer, 2004), but others have found the opposite effect (Poppo \& Zenger, 2002). As we will 
show below, the coordination perspective offers one explanation of that puzzle (for other explanations, see Puranam \& Vanneste, 2009).

The coordination perspective on alliance design. The preceding discussion assumes that actors choose formal and informal governance arrangements primarily to alleviate cooperation concerns. But as they draw up alliance contracts, organizations may also seek solutions to anticipated coordination challenges (Gulati et al., 2005; Vlaar et al., 2006; White \& Lui, 2005) or apply lessons of previously encountered coordination challenges (Litwak \& Hylton, 1962). Such a coordination perspective on alliance-design decisions - specifically, partners' choices of contractual structure and specific contractual clauses_-is receiving increasing attention.

More recent research has begun to consider how such formal structures as dedicated joint-venture organizations and detailed contracts can address not only cooperation issues but also coordination issues (Gulati et al., 2005; Puranam \& Vanneste, 2009; Vlaar et al., 2006; White \& Lui, 2005). As we noted in our description of the structural school of thought on inter-organizational coordination, joint-venture structures can facilitate coordination by providing robust authority structures and enforcement mechanisms, dedicated staff, and opportunities to devise structures and procedures that fit the purpose of the alliance (Gulati \& Singh, 1998). Detailed contracts can help address coordination challenges (Mellewigt et al., 2007; Reuer \& Arino, 2007) by specifying tasks, roles, and responsibilities (Carson et al., 2006; Mayer \& Argyres, 2004); contingency plans and responses (Ring \& Van de Ven, 1994), and information-sharing and feedback channels (Argyres \& Mayer, 2007) to ensure smooth operation. Forwardlooking firms are likely to weigh those benefits against the higher costs of both JVs and 
detailed contracts and to select more formal governance when their coordination needs are highest, such as in situations characterized by high task uncertainty and interdependence (Gulati \& Singh, 1998; Mesquita \& Brush, 2008), incompatibilities stemming from partner diversity (White, 2005), or high costs for coordination failure (Mellewigt et al., 2007).

Firms may design contractual clauses at the outset not only to meet anticipated coordination requirements but also in response to experience gained from past collaborations. ${ }^{18}$ Though they do not always frame the debate explicitly in coordination terms, some scholars have argued that partner-specific experiences will influence which coordination issues partners anticipate and which coordination mechanisms they use in those partnerships. Some of the mechanism for coordination that partners develop over time can become routines that are implemented informally (Reuer \& Arino, 2007), but some will be formalized in contracts that effectively serve as "repositories of knowledge" distilling the lessons of past coordination failures (Argyres \& Mayer, 2007; Argyres, Bercovitz, \& Mayer, 2007). For example, partners' experiences of misunderstandings resulting from poor informal communication in prior alliances may prompt them to formalize information-exchange provisions in their subsequent alliance contracts (Mayer \& Argyres, 2004).

${ }^{18}$ Such experiential learning also occurs in the design of cooperation-related contractual clauses. However, coordination-related clauses are usually more idiosyncratic to the task and the partners, while cooperation-related clauses are frequently standardized into legal boilerplate (Vanneste \& Puranam, 2010). Furthermore, knowledge of the design of coordination-related clauses typically resides with the organization's managers, while the design of cooperation-related clauses is often handled by external counsel (Argyres \& Mayer, 2007). 
Discussion. Our review of the drivers of alliance-design decisions reveals some overlap in the predictions of the two perspectives. Formal contracts and JV structures can be used to alleviate both cooperation- and coordination-related concerns arising from the task structure. For example, the empirical finding that R\&D-intensive partnerships tend to employ more hierarchical joint-venture governance structures may be due to anticipated cooperation-related challenges like the difficulty of monitoring and control (Oxley, 1997; Pisano, 1989), or to ex ante coordination-related challenges like the likely complex and ambiguous interdependencies that arise in such ties (Gulati \& Singh, 1998). This overlap suggests the need for better disentangling the actual mechanisms behind certain taken-for-granted empirical relationships in alliance design.

However, the coordination perspective offers more than further justification for some cooperation-based predictions. For example, it can transcend the simple dichotomies of equity vs. non-equity structures, and even broad categorizations of contractual items used in prior research from a cooperation perspective, to provide greater insight into the specific coordination mechanisms actually used in alliances. It raises a host of interesting questions. For example, are formal hierarchical structures universally preferred for alliances that involve significant coordination requirements? Or are more informal and flexible structures, or structures more closely integrated with the parent organizations, more beneficial to achieve greater coordination?

Finally, the coordination perspective can shed light on some puzzling contradictions within the cooperation perspective, such as the paradox of simultaneous increase in trust and contractual complexity in some repeat partnerships (Poppo \& Zenger, 2002). This finding appears to conflict with the predictions of sociologists and 
social psychologists that increased trust arising from repeated interactions will reduce the need for contractual safeguards (Macaulay, 1963; Malhotra \& Murnighan, 2002; Molm et al., 2000). This anomaly could be explained by the fact that repeated ties lead to increased partner-specific learning that in turn reduces coordination costs which is subsequently reflected in looser contracts. In support of such an argument, a separate analysis of cooperation- and coordination-related contractual clauses reveals that only the latter increase in number with partner-specific experience (Vanneste \& Puranam, 2010). As a result, it is likely that partners' cooperation and coordination experiences have distinct effects on design choices, and points out promising venues for research. For example, under what circumstances is learning from past alliances carried over into formal contracts, and when is it discarded? When is learning from past experiences codified in contracts - thus increasing contractual complexity — and when is it embodied in informal routines that reduce the need for codification, thus decreasing contractual complexity? What are the performance consequences of such transfers of experience? Is experience more likely to facilitate coordination, or to impair it as lessons learned are mistakenly applied to the wrong situations?

\section{Post-Formation Dynamics}

No matter how carefully organizations strategize about partner selection and initial governance setup, many scholars believe that "managing the alliance relationship over time is usually more important" (Doz \& Hamel, 1998: XV). After all, it is during actual implementation of the alliance that partners may begin engaging in opportunistic behavior that leads to cooperation failures. And it is during implementation that actual coordination challenges become apparent and coordination failures occur. The research 
on post-formation dynamics in alliances largely seeks to explain how and why partners implement and change the alliance agreement over the course of the relationship. Particular attention is paid to how shortcomings in the initial alliance setup, endogenous developments within the alliance, and shifts in its external environment influence partners' implementation and adaptation choices.

The cooperation perspective on post-formation dynamics. The cooperation perspective on post-formation dynamics explains implementation choices and alterations of alliance arrangements as functions of either (1) partners' attempts to address or exploit openings for opportunistic behavior, or (2) partners' changing levels of commitment and trust.

Some efforts to alter initial cooperation agreements are pursued to fix flaws in the initial design, or to accommodate the changing goals of one or both the partners. Assuming bounded rationality, alliance managers are apt to make errors of commission or omission in their initial alliance designs that provide openings for opportunistic behavior. For example, they may choose formal structures that later turn out to be inappropriate (Sampson, 2004) or fail to specify important contractual clauses, such as monitoring or exit provisions (Gulati, Sytch, \& Mehrotra, 2008). The greater the vulnerability or perceived disadvantage a partner feels due to weak contractual safeguards (Reuer \& Arino, 2002), the more likely they are to bargain for corrective bilateral/multilateral solutions in order to better align incentives and prevent cooperation failures. Emergent internal developments, such as a partner's strategic reorientation, can also lead to misalignment of incentives and thus may necessitate renegotiation and 
readjustment of initial agreements to ensure sustained cooperation in the relationship (Bamford et al., 2004).

Partners' attempts to "fix" agreements to ensure cooperation may, of course, embody agendas other than the equity or stability of the partnership. Specifically, partners may seek to exploit advantages in bargaining power to extract a more favorable agreement about contributions and payoffs in the alliance. Asymmetric bargaining positions may date back to the very beginning of the relationship: for example, higher asset specificity increases the likelihood of renegotiation, arguably because of the asymmetries in dependence that it creates (Reuer, Zollo, \& Singh, 2002). But such asymmetries can also arise endogenously in the course of the alliance: for example, in learning alliances the fastest-learning partner may be able to force a renegotiation of terms and to demand concessions from slower-learning partners (Hamel, 1991; Inkpen \& Beamish, 1997; Khanna, Gulati, \& Nohria, 1998). As a rule, any initial contractual deficiencies and emergent internal or external developments can lead to incentive misalignment and promote renegotiation of the arrangement.

To characterize the post-formation phase as a purely economically motivated struggle for a bigger portion of the pie and more advantageous terms would be to ignore social dynamics that can also explain formal and informal adjustments to these agreements during this phase. From a cooperation lens, the dynamics within these partnerships can also be positive in that they lead to greater cooperation and reduced risk. To the extent that the alliance satisfies partners' expectations, they may experience a virtuous cycle of escalating relational commitments and trust (Doz, 1996; Larson, 1992; Ring \& Van de Ven, 1994). Joint accomplishments can create a feeling of strategic 
interdependence and anticipation of greater gains in the future, which can increase the partners' commitment to the stability of the relationship (Heide \& Miner, 1992; Poppo et al., 2008). And an accumulating track record of mutual honesty can solidify personal bonds between boundary spanners, engender positive affect (Lawler, Thye, \& Yoon, 2000; Uzzi, 1999), and foster interpersonal trust (Gulati \& Sytch, 2008), which over time can become institutionalized as inter-organizational trust (Zaheer et al., 1998). Enhanced commitment and trust can in turn facilitate renegotiation of formal agreements, since actors are less likely to suspect underhanded motives (Reuer et al., 2002). Commitment and trust also facilitate informal adaptation in the absence of changes to formal documents, which is especially valuable in unpredictable and turbulent environments (Ring \& Van de Ven, 1992).

The relational attachment processes can also work in reverse, leading to more rigid and fragile cooperation. Unmet expectations and perceptions of opportunism can undermine partners' commitment and trust and diminish their ability to negotiate mutually satisfying solutions (Arino \& de la Torre, 1998). Disappointed partners may insist on rigid adherence to the language of the contract (Faems, Janssens, Madhok, \& Van Looy, 2008), thus reducing the prospects of informal adaptation..

The coordination perspective on post-formation dynamics. The post-formation phase of an alliance puts the partners' motivation and commitment to the test; it also exposes weaknesses in initially specified coordination mechanisms when the real coordination needs of the joint effort become apparent. Some of the adjustments over the course of an alliance that may be attributed to shifting cooperation concerns may actually be rooted in the changing dynamics of coordination. In fact, many real-world examples of 
contract alterations and organizational adjustments address elements more relevant to day-to-day coordination of activities than to prevention of opportunism or appropriation of benefits (Mayer \& Argyres, 2004). To some degree, this abrupt focus on coordination issues results from a lack of attention to coordination that is commonplace during earlier phases of the alliance life cycle; implementers are thus left to improvise and elaborate coordination mechanisms as the relationship evolves. The coordination perspective attributes such elaboration and adjustment of coordination mechanisms to partners' efforts to enhance the efficiency and effectiveness of coordination, informed by effective or dysfunctional learning processes.

Over the course of an alliance, participating organizations learn about their partners and about the task they aim to perform (cf. Reuer et al., 2002). At the outset, they may harbor incomplete (or flat-out wrong) assumptions about their partners' resources, capabilities, and structural and cultural idiosyncrasies, and about the coordination requirements of the joint task. To the extent that their notions are erroneous — or that they do not reconcile their differences in perception — their specification of critical subtasks, interdependencies, and contingencies are apt to be incomplete or mistaken, and coordination failures more likely. Over time, however, the partners may develop a more accurate shared understanding of their joint task's coordination requirements, and of how their own organizational characteristics can complicate or help resolve coordination issues. For example, a small entrepreneurial firm may gradually grasp that its informal decision-making process does not work in collaborations with large bureaucratic organizations (Doz, 1996); and a U.S. company may learn how to navigate its cultural and linguistic differences with its foreign partners 
(White, 2005). Much of this task-related learning is based on trial and error, on insights gained from coordination failures, and on near-misses in the course of the relationship.

As an alliance unfolds, the partners may choose to alter and adapt organizational and administrative arrangements made for the alliance at the outset to improve the efficiency and effectiveness of coordination, and to improve alliance performance (Gulati, Lavie, \& Singh, 2009; Zollo et al., 2002). They may revise their division of labor, formalizing their learning in contract clauses that specify accountability, contingency planning, and communication channels (Argyres et al., 2007; Mayer \& Argyres, 2004). But a host of informal adjustments are possible too. Growing familiarity with partners' key decision-makers allows for formation of informal joint problemsolving workgroups (Faems et al., 2008); better mutual understanding supports development of a shared knowledge base and shared language, both of which smooth communication (Stuart, 1998; Uzzi, 1997); and improved understanding of causal links between individual actions and collective outcomes (Kogut, 2000) helps pinpoint opportunities for investment in relationship-specific assets to enhance compatibility (Dyer \& Singh, 1998). Ultimately, some of the partners' experiential learning will be incorporated into relationship-specific or more general routines that can improved coordination (Reuer \& Arino, 2007).

But inter-organizational learning processes do not always lead to better coordination (Goerzen, 2007; Hoang \& Rothaermel, 2005). Mutual learning may prove to be maladaptive if locks partners into competency traps and renders them unwilling to abandon established but suboptimal inter-organizational processes and routines (Levitt \& 
March, 1988). ${ }^{19}$ The consequences of such rigidities may be especially damaging when the external environment or the nature of the alliance changes, requiring new formal structures and informal routines wholly unlike those the partners have previously used (Zollo \& Reuer, 2010).

Discussion. In conclusion, the coordination perspective adds nuance to the cooperation-based view of post-formation dynamics. Learning about partners' commitments and intentions is an important aspect of the development of a cooperative relationship, but the coordination perspective also emphasizes learning about the task, about partners' capabilities and resources, and about how they can be most efficiently combined. There are many opportunities here for future research to advance our understanding of when and how formal and informal coordination mechanisms are changed, and how such changes affect the efficiency and effectiveness of coordination (for a promising start, see Argyres \& Mayer, 2007; Vanneste \& Puranam, 2010; Zollo \& Reuer, 2010).

Our review also suggests a possible tension between cooperation- and coordination-related considerations during the post-formation phase: open communication and knowledge sharing may be desirable from a coordination standpoint, to reduce the likelihood of incompatibilities, omissions, and misallocations, but undesirable from a cooperation standpoint if the likelihood of knowledge spillovers and misappropriations increases in the process. By implication, more extensive coordination provisions may require a certain level of cooperativeness and trust among partners.

19 Such rigidities may be harder to overcome in alliances than in organizations because process changes can rarely be imposed by fiat and typically must be negotiated among the partners (Rogers \& Whetten, 1982). 
Conversely, effective inter-organizational coordination that minimizes unanticipated behaviors and problems during operation of the alliance may be instrumental in sustaining and promoting partners' commitment and trust. The next section extends this line of reasoning and elaborates different models of how cooperation and coordination can be interrelated, and how they affect alliance outcomes. 


\section{INTEGRATING THE COOPERATION AND COORDINATION PERSPECTIVES}

Our review of cooperation- and coordination related research so far has shown that most studies consider cooperation and coordination issues in isolation from each other. A few recent studies, however, have begun to examine how cooperation and coordination issues interrelate, how they independently or jointly impact alliance outcomes, and how they may in turn by influenced by those outcomes. Some studies imply that the level of cooperation within a relationship can influence its adaptiveness and thus the quality of the coordination - and vice versa (Faems et al., 2008). Others point towards the possibility that cooperation and coordination-related relationship characteristics shape performance interactively rather than independently (Luo, 2002). Still other studies suggest that key aspects of the relationship, such as the level of cooperation, could themselves be shaped by partners' subjective performance evaluations (Ring \& Van de Ven, 1994). To date there is little systematic discussion of the theoretical foundations of those relationships between cooperation, coordination, and performance, and even less of their theoretical and practical implications.

In this section, we will examine different ways in which the relationship among cooperation, coordination, and performance can be conceptualized, and what each approach means for alliance researchers and practitioners (see Table 3). We suggest that scholars' perspectives on the relationship between cooperation and coordination differ along two dimensions: (1) are cooperation and coordination issues and solutions independent or interdependent? and (2) is the relationship between cooperation and 
coordination objectively identifiable or subjectively constructed? We build on these two distinctions to articulate three conceptions. The independent model, implicitly assumed in much of the literature, is a simple model in which cooperation and coordination do not influence each other, and both have a simple additive relationship to performance. This model has significant limitations in its portrayal of alliances. The interdependent model examines the implications of mutual influence between cooperation and coordination and their superadditive effect on performance, due either to synergies or to mutual reinforcement. This model provides a richer and more realistic conceptualization of alliance phenomena. Finally, we suggest an interpretive perspective, which allows for the possibility that misconstruals and biased attributions of relationships among cooperation, coordination, and performance shape alliance decisions and outcomes (see Table 3). The interpretive view of the relationship between cooperation, coordination, and performance is least explored in the existing alliance literature, but holds significant promise for future research as it highlights the unexplored cognitive micro-foundations that may underlie alliance dynamics.

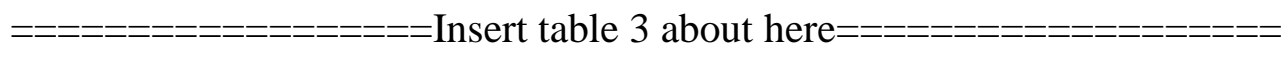

\section{The independent model}

The most basic approach to the question of how cooperation and coordination interrelate suggests that the two phenomena are independent of each other and have a simple additive effect $(2+2=4)$ on alliance outcomes. This additive effect relies on the assumption - implicit in most studies that consider only one or the other in isolation, and explicit in some studies that consider both phenomena (Gulati \& Singh, 1998) - that 
cooperation and coordination issues in a partnership occur independently of each other, and independently affect alliance outcomes. ${ }^{20}$ Cooperation- and coordination-related successes are assumed to have separate effects on alliance outcomes; for instance, better cooperation is assumed to lead to higher performance independent of coordination efforts and vice versa (Das \& Teng, 1998; Heath \& Staudenmayer, 2000; Kretschmer \& Puranam, 2008). Cooperation and coordination problems are assumed to "pile up" in an alliance, but not to influence each other. They can thus be tackled separately with distinctive remedial interventions, e.g., the threat of sanctions/penalties to improve cooperation, or better planning to improve coordination.

The assumption of independence does not preclude, however, that some interventions can affect both cooperation and coordination. For example, the JV form promotes clear and focused interaction - a coordination benefit - and ensures that activities and information intended to be outside the scope of the alliance are not transparent to or shared with partners - a cooperation benefit (Oxley \& Wada, 2009). Investments in systems or process integration can improve coordination but simultaneously constitute relationship-specific investments that can serve as "mutual hostages" and reduce relationship-ending opportunism (Dyer, 1997). Likewise, informal team-building efforts can enhance both trust and relational attachment, a cooperationrelated benefit, and shared understanding of critical interdependencies, a coordinationrelated benefit.

${ }^{20}$ Most studies implicitly assume either cooperation or coordination problems to be solved or trivial; only few make this assumption explicit (see, e.g. Puranam, Singh, \& Chaudhuri, 2009 for exception). In both cases, the exclusive focus on either cooperation or coordination systematically precludes consideration of possible influences of one on the other. 
The normative implication of the model is that alliance managers can tackle cooperation and coordination issues separately_cooperation and coordination experts or teams could work independently — and that even an exclusive focus on one or the other would be a feasible approach to managing alliances. By extension, partners might also be able to choose, strategically and situationally, to concentrate their attention and resource allocation exclusively on cooperation or coordination if doing so seems likely to further alliance goals. Such strategic choices may depend on partners' assessment of (1) the primary challenges of the alliance, and (2) which sphere they can more feasibly and successfully influence.

First, the scope and specific tasks of the alliance would influence partners' perception of where the primary challenges lie and thus bias them toward cooperation or coordination (Mellewigt et al., 2007; Mesquita \& Brush, 2008). For example, in alliances whose purpose is integrating logistics processes, such as those between manufacturers and shipping companies, the predominant issues are likely to pertain to coordination. In alliances engaged in the unidirectional transfer of know-how, by contrast, issues of appropriation of intellectual property loom large, and thus cooperation issues may command the most attention(Oxley, 1997).

Second, partners' choices of focus depend on which sphere they believe they can influence more easily. This path of least resistance may be particularly prevalent when partners cannot improve cooperation and coordination simultaneously or to the same degree, and therefore have to tolerate known shortcomings that are not easily fixed. In an exploratory R\&D alliance, for example, joint activities and crucial interfaces may be difficult to anticipate and plan; thus partners may focus on maintaining and enhancing 
cooperation to ensure continuing engagement and commitment despite inefficiencies or false starts attributable to coordination difficulties.

Such substitutions suggest that cooperation and coordination efforts may be to some degree equifinal in their contribution to attainment of alliance goals. In the sense that either cooperation or coordination efforts can help reduce overall risk (relational and operational risk combined) in the relationship or lower the overall cost of cooperation and coordination, and thus contribute to partners' satisfaction and belief in the feasibility of the collaborative effort, both may indeed have substitutive effects on alliance outcomes.

This independent model reviewed above has two limitations. First, not all cooperation and coordination efforts are compatible. Thus while a particular cooperation agreement and particular coordination mechanisms may be effective at addressing specific issues in their separate realms, when implemented together they may conflict and negatively impact alliance outcomes. For example, highly restrictive and punitive intellectual-property ownership clauses borne out of R\&D alliance partners' knowledgeleakage and misappropriation worries may be effective at preventing cooperation failures. But they may clash with coordination provisions for extensive knowledge sharing and communication, implemented to handle the difficult-to-predict interdependencies and high uncertainty of R\&D efforts (Hamel, 1991; Larsson, Bengtsson, Henriksson, \& Sparks, 1998; Pisano, 1989).

Second, in extreme circumstances the assumption of independence and substitutability may break down. It is difficult to conceive of effective coordination efforts in the absence of any cooperation among partners: given that inter-organizational 
coordination requires some effort from the participants, a minimum level of sustained and predictable commitment to joint effort is a prerequisite for any alignment of actions (Gerwin \& Ferris, 2004). And to the degree that coordination serves the attainment of alliance goals, it is necessarily evaluated with reference to those goals (i.e., the cooperation agreements). At the same time, cooperation in the absence of coordination efforts seems similarly impossible: cooperation entails goal-directed collective action, and thus requires a certain minimum of coordination (e.g., incorporation of alliancerelated activities and goals into partner organizations' portfolios of activities and goals). Following this reasoning, cooperation and coordination appear to be necessary and complementary elements in any alliance - an assumption that the second interrelationship model builds on.

\section{The interdependent model}

Some studies have suggested that cooperation and coordination depend on and influence each other (for the intra-organizational context, see e.g., Kretschmer \& Puranam, 2008; for the inter-organizational context, see e.g., McEvily, Perrone, \& Zaheer, 2003), and have a joint impact on alliance outcomes that exceeds their combined individual impacts. We call this the interdependent model. ${ }^{21}$ It addresses a key limitation of the independent model of cooperation and coordination highlighted in the previous section: for cooperation to have any positive impact on alliance outcomes, some minimal coordination must have been achieved, and vice versa. In other words, partners will not

21 The interdependencies can play out at two different levels. First, the quality of the cooperation is dependent on the quality of the coordination and vice versa. Second, the marginal effect of quality of cooperation on outcomes is dependent on the quality of the coordination and vice versa: in other words, there is a superadditive effect of cooperation and coordination on performance. 
be able to effectively coordinate in the absence of sustained agreement and reliable commitment regarding the inputs and intended outputs of the partnership; nor will they be able to put the pledged inputs to productive use without at least a rudimentary agreement on coordination. Though typically not articulated in terms of cooperation and coordination, such an interdependent, mutually required "minimum-threshold" conception has been put forth for both the intra- and inter-organizational contexts (Bachmann, 2001; Dosi, Levinthal, \& Marengo, 2003; Gulati, 2010).

Assuming that this "minimum-threshold" condition is met — that minimum levels of cooperation and coordination have been achieved - scholars have focused on whether cooperation and coordination in combination produce a superadditive effect on alliance outcomes $(2+2=5)$. Two alternative logics, whose assumptions differ about how tightly cooperation and coordination issues are interwoven, can account for such a superadditive effect: inherent complementarity, which suggests that a change in the extent or quality of cooperation changes the impact of existing coordination efforts and vice versa; and mutual incremental reinforcement, which suggest that a change in the extent or quality of cooperation leads to subsequent changes in coordination efforts and vice versa, resulting in an interactive effect over time.

Inherent complementarities. According to the logic of complementarity, increasing cooperation should enhance the marginal impact of a given level of coordination and vice versa. This logic can be understood in a general sense, such that better cooperation makes any coordination effort more beneficial and vice versa, or in the more specific sense that a particular cooperation provision enhances the effectiveness of a particular coordination mechanism or vice versa. For example, Poppo and Zenger (2002) 
showed that the benefits of relational governance (a cooperation provision) are magnified by extensive contractual clauses for the administrative implementation of the relationship (a coordination mechanism). Luo (2002) suggested that contractual adaptiveness - an important aspect of effective coordination-has the greatest impact in high-trust relationships. ${ }^{22}$ The anticipation of such complementarity benefits may also drive decisions to form alliances with potential partners that rank highly on cooperation criteria (e.g., prior relationships or indirect connections) and on coordination criteria (e.g., compatibility of resources) (Mitsuhashi \& Greve, 2009).

The complementary effects reported in these studies suggest that cooperation and coordination issues may be intricately interwoven, especially when it comes to adaptiveness, as in Luo's (2002) study, and sustained commitment to the alliance, as in Poppo and Zenger's (2002). Adaptiveness can be explained as a result of high-quality cooperation among partners that makes it easier to adjust existing coordination mechanisms flexibly. Partners will be less prone to suspect hidden agendas and disadvantageous consequences of such adjustments. Hence successful coordination of activities, even in the face of unanticipated contingencies, becomes less effortful and costly. In contrast, low cooperativeness can turn elaborate coordination provisions into a liability as partners cling to ineffectual, outdated mechanisms.

Sustained commitment to the alliance can be similarly explained as a complex interplay between cooperation and coordination. Detailed up-front specification of

${ }^{22}$ Note that in the Poppo and Zenger (2002) study, the sheer extent of coordination arrangements produces a complementary benefit to cooperation arrangements, independent of the effectiveness of those arrangements (i.e., their proximal outcomes). In Luo's (2002) study, however, it is the quality of cooperation, i.e., the level of achieved trust that underlies such complementarity. 
coordination mechanisms (during the design stage) makes successful coordination over the course of the partnership more likely, ensures efficient use of partners' contributions, reduces process losses, and provides clear guidelines for how partners will interact. All of this improves foreseeability, which not only facilitates coordination but also reduces the partners' perceived level of overall risk: given the solid administrative basis of the partnership, partners have transparency over what is going on (Carson et al., 2006). Transparency and communication among partners enhance shared understanding of mutual expectations and alleviate fears of partner misconduct, and can engender trust and group identity (Agarwal, Croson, \& Mahoney, 2010; Zeng \& Chen, 2003). These conditions make premature termination of the relationship less likely: partners are unlikely to pull the plug and reduce contributions or commitment immediately when the partnership encounters small internal or external challenges; they may even have prespecified coordinated responses to such occurrences.

Mutual incremental reinforcement. According to reinforcement logic, more extensive cooperation (e.g., increased strategic interdependence and more ambitious goals) and/or good cooperation outcomes (equity, trust, goal attainment, etc.) encourage subsequent strengthening of coordination efforts. Inversely, more extensive coordination (deeper integration of partners' processes and systems) and/or good coordination outcomes (effectiveness and efficiency) encourage subsequent increase in the extent of cooperation (i.e., more contributions or additional goals), possibly leading to a positive spiraling effect. As a result, cooperation/coordination synergies would be achieved over time even if no complementarity effects existed at any given moment. The mechanisms that cause such reinforcement and reinforcement loops warrant some elaboration. 
Empirical studies suggest that the extent of inter-organizational coordination may change in response to strategically chosen levels of interdependence (Dyer, 1996, 1997). Similarly, high levels of cooperativeness can promote greater willingness to invest in relationship-specific assets (co-located facilities, integrated IT systems, shared routines and structures) as organizations gain confidence that their partners will not exploit this new vulnerability via holdup (Larson, 1992). A number of studies have also suggested that trust alleviates appropriation and misuse worries and thus facilitates the exchange of fine-grained and sensitive information that may be critical to successful coordination (Kale et al., 2000; Uzzi, 1997). Lastly, successful cooperation promotes continuance of the relationship and thus opportunities to standardize and formalize agreed-on processes over time, leading to more elaborate coordination mechanisms (Poppo \& Zenger, 2002: 713).

Coordination can also promote more extensive cooperation. Formalized procedures for problem solving, decision making, and conflict resolution can enhance the predictability of interactions and give partners a sense of procedural justice (Luo, 2005): problems and tensions are resolved according to mutually agreed-on rules and procedures, which over time encourage partners to extend the scope of their cooperation, i.e., to add activities and domains that they may previously have considered too sensitive or risky. Similarly, the efficiency benefits of successful coordination may lead partners to make a more positive cost-benefit assessment of the alliance as a whole, and to unilaterally or multilaterally commit more resources.

Mutual positive reinforcement between levels of cooperation and coordination can lead to a virtuous cycle whereby cooperation enhances coordination by facilitating 
information exchange and relationship-specific investments, and coordination in turn encourages cooperation by promoting clear standards of behavior and performance, procedural justice, and perceptions of efficient value creation. Such positive cycles, predicted originally by Ring and Van de Ven (1994), have been empirically identified in some real-world alliances (Doz, 1996; Faems et al., 2008).

Reinforcement loops are not exclusive to cooperation and coordination efforts; they characterize cooperation and coordination problems too. Mutual reinforcement of such problems suggests that they not only pile up but also spill over into each other, and can lead to co-erosion of cooperation and coordination. Economic inefficiency due to coordination failures can erode partners' commitment to the alliance over time. When cooperation failures fuel worry about the stability and benefits of the relationship, partners may doubt that effortful forms of coordination are worth the effort. Likewise, low cooperativeness can manifest itself in coordination activities that minimize individual efforts (e.g., refusal to adjust internal technical and administrative standards to partners' standards), minimize individual risks (e.g., refusal to share proprietary knowledge), and maximize individual benefits (e.g., assertion of decision-making rights and access to proprietary knowledge). Founded or unfounded suspicion about opportunistic behavior can lead to lingering conflicts over coordination, and may lead partners to seal off information critical to coordination, ultimately causing unresolved coordination issues to worsen and coordination gaps to widen (Arino \& de la Torre, 1998).

The normative implications of both complementarity and reinforcement logic seem to support a balanced approach, equally attentive to ensuring high levels of cooperation and coordination at the beginning of an alliance. Such an approach may 
trigger complementarities, and can kick off positive reinforcement loops starting from either cooperation or coordination. The complementarities logic in particular suggests that a single-minded focus on cooperation or coordination issues alone may not be successful. The reinforcement logic, on the other hand, suggests that alliance partners may benefit from positive momentum once they have achieved a certain level of cooperation and coordination success, an incremental and apparently perpetual increase in one factor following on the successful outcomes of the other.

But this more complex and dynamic perspective on the relationship between cooperation and coordination and its impact on alliance outcomes has a number of limitations. First, both logics leave unanswered whether the positive and negative influences of cooperation on coordination and vice versa are symmetrical - that is, whether weaknesses erode strengths, or strengths help repair weaknesses. For example, if alliance partners are mutually wary but have robust planning procedures in place, would successful coordination help to improve trust? Or would the trust problems undermine the coordination successes? In general, strong cooperation and weak coordination may be a better basis for sustained joint effort than strong coordination and weak cooperation: high mutual trust and commitment may be more likely to motivate partners to double down to solve remaining operational issues than would "mere" operational efficiencies to cause them to revise their assessments of cooperativeness in the relationship. However, alliance partners' differential capabilities for fostering trust or figuring out complex task interdependencies may reverse that prediction.

Second, both the complementarity and reinforcement logics leave open whether positive joint effects occur in perpetuity, and irrespective of the level of cooperation and 
coordination achieved, or decrease at certain thresholds or under certain conditions. It is unclear, for example, at what level of cooperation or coordination positive reinforcement loops begin and under what conditions they may break down. An infinite positive loop seems unrealistic, as alliance partners may not infinitely escalate their commitment, or become infinitely trusting, merely because inter-organizational coordination has been increasingly successful; they may have inherent limits on what scope of cooperation they find desirable and how much they can trust (Oxley \& Sampson, 2004). Likewise, some partnerships may struggle to match the growing scope of their alliance with more extensive coordination — the complexity of the relationship may exceed their abilities. From a behavioral perspective, it is questionable that alliance managers will want to or be able to pursue such reinforcement loops ad infinitum. Some scholars argue that the evolution of cooperation and coordination does not necessarily follow a positive or negative spiraling path continuously; instead it traces more complex, less predictable patterns over the course of the alliance (Van de Ven \& Walker, 1984).

Complex evolutionary patterns of cooperation and coordination may be explained in part by partners' subjective and inter-subjectively negotiated perceptions of alliance performance and challenges. Thus a perspective that attributes alliance outcomes to cooperation or coordination issues can help explain how reinforcement loops begin and

end, and whether the respective influences of cooperation and coordination outcomes on subsequent cooperation and coordination efforts differ.

\section{Towards an interpretive perspective}

Given the important role of partners' subjective understandings of cooperation and coordination issues in an alliance, we can usefully assume that partners' 
understanding of the relationship between cooperation and coordination and its impact on performance outcomes is also shaped by subjective interpretations (Van de Ven \& Walker, 1984). However, disentangling cooperation and coordination issues in an alliance, and accounting for their respective or joint contributions to alliance success (or failure), can be difficult for alliance managers. In our discussion of the interpretative perspective we suggest how heuristics and biases - specifically, attribution and confirmation biases - may influence alliance managers' interpretations, and point out implications for partners' behavior and for alliance outcomes.

Attribution theory suggests that decision makers variously attribute causality to the self, to someone or something outside the self (Weiner, 1985), or to a relationship with another person (Eberly, Holley, Johnson, \& Mitchell, 2011). We argue that relational attributions can be further distinguished as attributions to cooperation- or coordination-related factors: "We failed because we did not trust each other" or "We succeeded because our joint efforts followed a carefully devised plan.” Why are such post-hoc attributions important in alliances? Attributions of alliance success to partners' efforts (whether cooperation- or coordination-related), as opposed to fortuitous external circumstances, are likely to strengthen cooperation. Successful outcomes reduce uncertainty about the profitability of future interactions, and thus deepen the "shadow of the future" between the two parties. Furthermore, satisfaction with alliance outcomes is likely to strengthen mutual "psychological contracts" (Ring \& Van de Ven, 1994), in turn facilitating communication, information sharing, and flexible adaptation.

Misattributions of alliance success, however, can be detrimental for an alliance. If cooperation is incorrectly perceived as the key reason for success, alliance partners may 
mistakenly underemphasize the importance of coordination in future partnerships. By the same token, if coordination is inappropriately credited with saving the alliance despite perceived cooperation problems, partners may overdepend on smart coordination as a magic bullet for all kinds of problems in their alliance. Both kinds of misattributions misattribution of success to cooperation or to coordination - may be transferred as experiential learning, and thus may perpetuate mistaken beliefs about what 'really' drives alliance outcomes across multiple partnerships (Zollo \& Reuer, 2010). ${ }^{23}$

Attributing alliance failure can be even more consequential, because cooperation and coordination failures imply different solutions. A perception of cooperation failure often raises doubt about the partner's essential character, which can cause unwillingness to "play the sucker" or contribute further to the relationship (Kerr, 1983; Schnake, 1991). Especially in formerly high-trust situations, the feeling of betrayal can provoke irrational vendetta-style responses (Uzzi, 1997). Such actions can provoke retaliation (especially if the target perceives itself to be unfairly blamed), potentially making attribution of performance shortcomings to cooperation failure a self-fulfilling prophesy. If the reason for failure is misidentified as cooperation-related, alliance partners may "throw out the baby with the bathwater" in the sense that they may terminate a potentially productive relationship when relatively minor coordination tweaks could have remedied the problem.

${ }^{23}$ Misattributions of alliance success can initially fuel the reinforcement loops between cooperation and coordination but can also account for their eventual breakdown. There are limits to how much investment in cooperation will pay off as better coordination and vice versa. If they overinvest in the wrong tools to insure collaboration success, actors may not be spending their resources wisely and may leave a real problem to fester. 
When attributing failure solely to coordination difficulties, by contrast, partners may pursue a more cool-headed, bureaucratic analysis. Was the coordination failure due to fundamental incompatibilities between the organizations? What kinds of adjustments are necessary to overcome it? If both sides decide that the problem is fixable and the costs tolerable, they may attempt to salvage the relationship by improving routines, enlarging the interaction interface (Faems et al., 2008), and/or investing more in cospecialized coordination-enhancing assets (Larson, 1992). If the failure is misidentified as coordination-related, partners may "throw good money after bad" by investing further in coordination but avoiding a frank cooperation-focused conversation with their partners.

An emphasis on cooperation- or on coordination-related issues respectively to account for alliance successes (or failures) may be based on systematic attributional biases. Prior research suggests that individuals evaluate cooperation and coordination issues in collaborative efforts differently. A recent study shows, for example, that positive affect toward a partner is a precondition for individuals to even consider and evaluate the partner's competences and abilities (Casciaro \& Lobo, 2008). This finding suggests that organizations may consider partners' cooperativeness first; coordination issues are considered later, contingent on the prior assessment.

Biased assessments of the root causes of alliance success or failure may also depend on the degree of responsibility that partners feel for cooperation and coordination. Research on fundamental attribution bias suggests that individuals tend to attribute negative outcomes to inexorable external forces, and positive outcomes to personal ability (Hewstone, 1990; Ross, 1977). When rationalizing an alliance failure, an organization may thus focus on the issues it had least influence over. Coordination is 
largely a joint responsibility, and the focal organization could conceivably have made better plans, communicated more regularly with partners, etc. But it may feel that it had little influence over the degree to which others honored their commitments and cooperated. Thus lack of cooperativeness may be more readily identified as a root cause of failure.

However, an attributional bias toward invoking coordination issues to account for alliance performance shortcomings is conceivable too. Field and laboratory evidence suggests that the quality of the relationship between collaborators - a core aspect of cooperation — plays a key role in attributions of success and failure. Individuals tend to give the benefit of the doubt to those they perceive as members of an in-group, attributing success to their inherent character or ability while discounting failure as the product of external forces(Nisbett \& Ross, 1980). Likewise, Uzzi (1997) argued that trust is the instinctive tendency to assume the best about the other party. Thus trusting partners may tend to attribute alliance problems to technical challenges (e.g., incompatibilities between systems, products, etc.) that could not be overcome despite everyone's best efforts. The potential for the quality of the cooperation to distort attribution may imply asymmetric roles for cooperation and coordination in the evolution of the relationshipin other words, a high level of cooperation and a low level of coordination may be more conducive to relationship stability than the reverse (Casciaro \& Lobo, 2008). Whether and under what circumstances an attributional bias toward cooperation or coordination issues prevails is an empirical question for future research.

By extension, cognitive biases may also influence how decision makers think about the interrelationship of cooperation and coordination. They may have strong 
subjective preconceptions about what is really wrong, or what really works, in a particular partnership, and confirmation bias (Nickerson, 1998) may lead them to interpret various challenges and setbacks in keeping with those assessments. For example, preconceptions about low cooperativeness may make alliance managers highly aware of cooperation failures, but also cause them to explain coordination failures as ultimately rooted in cooperation deficiencies. By declaring cooperation problems to be the root cause of all problems in the alliance, they implicitly suggest interdependence between cooperation and coordination issues. Construing such an interdependent relationship allows partners to confirm and reinforce their preconception of fundamental cooperation problems in the partnership; coordination failures are thus interpreted as just another indicator of underlying cooperation problems. But the confirmation bias can work the other way too: partners who are convinced of each other's trustworthiness but who run into coordination problems may construe coordination and cooperation issues as independent and entirely unrelated. By precluding any possible interrelationship between the two, they avoid questioning their respective commitments and motivations.

An attribution-based perspective's emphasis on the subjective nature of performance evaluations and construals of the interrelationship between cooperation and coordination can have several normative implications. First, alliance managers need to be proactive about understanding the partner's attributions and construals, and about establishing shared understandings (Thomas \& Trevino, 1993). What they may perceive to be good-faith efforts, and easily fixable coordination hiccups could appear to their partners as evidence of shirking and fundamental untrustworthiness. Second, timely communication to align each other's perceptions of the alliance's status quo ought to be 
supplemented by open and frank discussions to resolve nascent and emerging concerns, whether cooperation- or coordination-related. Unilateral actions leave room for misinterpretation, and may transform what began as a coordination failure into a real cooperation failure that kicks off a vicious cycle of relationship erosion (Arino \& de la Torre, 1998).

\section{CONCLUSION}

This paper articulates the cooperation and coordination perspectives as distinct and complementary facets of collaboration in strategic alliances. The two perspectives can help identify different challenges and risks that alliance partners face, and highlight different sets of solutions that partners implement during the partner selection, alliance design, and post-formation phases to ensure collaborative success.

Neither perspective can singlehandedly provide a comprehensive account of alliances. In fact, the systematic application of the two perspectives across the alliance life cycle reveals that each in isolation can be highly reductionist and sometimes misleading in its explanation of behavior and outcomes. From the cooperation perspective, relational concerns dominate_-particularly concerns about partners' willingness to contribute to the alliance and equitably share its outcomes. The mantra here appears to be "If there's a will, there's a way!": as long as partners get along, agree on goals, and maintain their commitment to the joint effort, any organizational problem is assumed to be possible, even trivial, for partners to resolve. From the coordination perspective, technical and administrative concerns - especially doubts and anxieties about partners' ability to realize the value proposition that the partnership is predicated 
on-eclipse all other problems. A preoccupation with the minutiae of interdependencies and inter-organizational interfaces, and with partners' abilities to orchestrate and administer the joint effort, often takes for granted partners' motivation and interest in the attainment of joint benefits.

Integration of the two perspectives, then, seems to promise theoretically richer models of strategic alliances. However, our analysis of the alliance literature finds different conceptions of how cooperation and coordination issues interrelate and interact: simple independent/additive and interdependent/superadditive relationships are the most frequently proposed, but further elaboration of the underlying mechanisms and boundary conditions is warranted. In light of some of the limitations of the independent and interdependent approach, we suggest the subjective attributions of cooperation and coordination as a promising area for further exploration.

Our paper offers a number of suggestions for future research. First and foremost, we encourage scholars to utilize carefully specified measures of cooperation and coordination when examining alliancing behavior and explaining alliance outcomes, and to focus on explicating mechanisms that isolate and also connect cooperation and coordination issues. Given the variety of cooperation and coordination concerns that partners face, there are plenty of opportunities to reexamine, refine, and reconcile our existing theories of alliance formation and design: when and how do cooperation concerns dominate coordination concerns and vice versa, and what is the impact of a relative emphasis on one or the other, or a particular balance, on the subsequent evolution of the partnership? 
A systematic examination of the relationship between cooperation and coordination also provides an opportunity to revisit central concepts in prior research on alliances, such as alliance capability, alliance learning, and trust. For example, are there differences in how quickly organizations accumulate skills to anticipate and manage cooperation- and coordination-related issues? If perceptions of trustworthiness are based on ability (a coordination issue) as well as on benevolence and integrity (cooperation issues) (Mayer et al., 1995), which leads most quickly to accumulation or loss of trust?

Finally, our emphasis on subjective perceptions of cooperation and coordination dynamics encourages scholars to assess these perceptions more directly, and to examine how closely these perceptions align among partners. Understanding of how asymmetries of perception can arise and be sustained is still very rudimentary. (For an examination of trust asymmetries in an acquisitions context, see Graebner, 2009.) Another venue for investigation is the degree to which subjective perceptions jibe with or are decoupled from more objective measures of cooperation- and coordination-related events in the alliance. Partners' positive or negative impressions of cooperativeness and coordination success may linger despite measurable changes in both spheres. Some scholars suggest that perceptions of cooperation failure may be more damaging and persistent than perceptions of coordination failure (Ghoshal \& Moran, 1996), and thus may take longer both to repair and to fade from partners' minds.

Our framework for unpacking the key components of collaboration has several practical implications. Cooperation and coordination represent significant challenges to alliance managers, particularly because they cannot rely on traditional forms of authority to achieve either one. Clarifying the distinctions between cooperation and coordination 
problems, their specific root causes, and their remedies should enable alliance managers to more effectively diagnose cooperation and coordination problems, and increase their awareness that particular interventions may improve cooperation but not coordination and vice versa (e.g., Kretschmer \& Puranam, 2008). We also hope that the framework will alert managers that cooperation and coordination issues should be kept in mind throughout all stages of an alliance, and that alliances are unlikely to succeed unless both kinds of issues are addressed. During partner selection, they should consider not just levels of trust and alignment of incentives with prospective partners, but also the compatibility and complementarity of the relationship, in order to minimize coordination losses and maximize coordination gains. Similarly, governance should not limit itself to ensuring sufficient contractual protections (Parkhe, 1993) but should also incorporate understanding of the task requirements, allocation of responsibility, joint responses to contingencies, and interaction protocols that are critical to early coordination (Doz, 1996; Faems et al., 2008; Mayer \& Argyres, 2004). During the actual operation of the alliance, managers should monitor not just for emerging conflicts and misalignment of incentives but also for weaknesses in coordination and opportunities to promote partners' compatibility via mutual adaptation, learning, and co-specialized investments. Our framework may help guard against "coordination neglect" (Heath \& Staudenmayer, 2000), which leads managers to attend to cooperation issues at the expense of coordination problems.

Our framework also stresses understanding interconnections between cooperation and coordination in alliances. It reminds managers not to neglect the social needs of alliance partners, and to build trust and sustain commitment—even in partnerships that 
are primarily struggling with coordination issues_-because doing so may indirectly support coordination by providing for effective and open communication and flexible adjustments of alliance structures. Cooperation can beget coordination as partners become more willing to make relationship-specific investments. Likewise, coordination can breed cooperation via increasing joint satisfaction in the relationship and growing knowledge of each other and of the tasks. But cooperation and coordination may also hinder each other. The framework prompts practitioners to assess, on the one hand, partners' contributions and goals, and, on the other, anticipated coordination needs and partners' estimated coordination skills and capabilities. Further, it encourages practitioners to assess whether partners' contributions are sufficient or, alternatively, whether coordination requirements exceed their abilities such that ambitious goals may need to be scaled down.

Finally, our perspective can sensitize alliance managers to the adverse consequences of misattributions of cooperation or coordination failure. Contradictory attributions can create significant tensions in a partnership, which can in turn degenerate into full-scale vicious cycles of declining perceived cooperation and coordination. According to our perspective, alliance partners benefit from recognizing and acknowledging each other's idiosyncratic concerns: doing so can pave the way for shared understandings of cooperation and coordination issues, and for effective corrective measures to get a flailing partnership back on track. In short, the analytic benefits that our framework provides researchers may apply equally to practitioners. 
TABLES

\begin{tabular}{|c|c|c|}
\hline & Cooperation Perspective & Coordination Perspective \\
\hline $\begin{array}{l}\text { Substance of alliance } \\
\text { agreement }\end{array}$ & $\begin{array}{l}\text { What contributions are } \\
\text { made and what outcomes } \\
\text { are expected by alliance } \\
\text { partners }\end{array}$ & $\begin{array}{l}\text { How interactions are } \\
\text { organized by alliance } \\
\text { partners }\end{array}$ \\
\hline Key motivation & $\begin{array}{l}\text { Actively managing resource } \\
\text { dependencies and sharing } \\
\text { investment risk }\end{array}$ & $\begin{array}{l}\text { Actively managing task } \\
\text { interdependencies and } \\
\text { uncertainties in alliance }\end{array}$ \\
\hline Key concern/risks & $\begin{array}{l}\text { Relationship risk: unstable } \\
\text { commitments and hidden } \\
\text { motivations }\end{array}$ & $\begin{array}{l}\text { Operational risk: inability to } \\
\text { coordinate across } \\
\text { organizational boundaries }\end{array}$ \\
\hline What success looks like & $\begin{array}{l}\text { Stability, equity, goal } \\
\text { attainment in the } \\
\text { partnership }\end{array}$ & $\begin{array}{l}\text { Efficiency, effectiveness, } \\
\text { flexibility/adaptiveness of } \\
\text { joint action }\end{array}$ \\
\hline What failure looks like & $\begin{array}{l}\text { Shirking, holdup, } \\
\text { misappropriation }\end{array}$ & $\begin{array}{l}\text { Omission, incompatibilities, } \\
\text { misallocation }\end{array}$ \\
\hline Remedies to prevent failure & $\begin{array}{l}\text { Legal or private sanctions; } \\
\text { social sanctions; } \\
\text { identification and relational } \\
\text { attachment }\end{array}$ & $\begin{array}{l}\text { Hierarchies, authority, and } \\
\text { formalization; institutions } \\
\text { and conventions; inter- } \\
\text { personal linkages and } \\
\text { liaisons }\end{array}$ \\
\hline
\end{tabular}

Table 1. Comparison of the cooperation and coordination perspectives 


\begin{tabular}{|c|c|c|c|}
\hline & Partner selection... & Alliance design... & Postformation dynamics... \\
\hline $\begin{array}{l}\text { Cooperation } \\
\text { perspective }\end{array}$ & $\begin{array}{l}\text { •...based on prior partnering experience } \\
\text { Gulati, 1995b } \\
\text { Li \& Rowley, } 2002 \\
\text { Podolny, } 1994 \\
\text { •...based on indirect ties between } \\
\text { organizations } \\
\text { Chung, Singh, \& Lee, } 2000 \\
\text { Gulati \& Gargiulo, } 1999 \\
\text { Walker, Kogut, \& Shan, } 1997 \\
\text { •...based on partner's centrality and } \\
\text { status } \\
\text { Ahuja, 2000 } \\
\text { Ahuja, Polidoro, \& Mitchell, } 2009 \\
\text { Guler \& Guillen, } 2010 \\
\text { Podolny, 1994 } \\
\text { •...based on shared identity with partner } \\
\text { Ingram \& Inman, } 1996 \\
\text { Ingram \& McEvily, } 2007\end{array}$ & $\begin{array}{l}\text { •... relies on formal governance } \\
\text { structures and/or detailed contracts } \\
\text { to prevent exchange hazards } \\
\text { Hennart, } 1988 \\
\text { Oxley, } 1997 \\
\text { Pisano, } 1989 \\
\text { Sampson, } 2004 \\
\text { •...relies on social mechanisms such } \\
\text { as prior or indirect ties, reputation, } \\
\text { and shared nationality to prevent } \\
\text { exchange hazards and sustain } \\
\text { commitment } \\
\text { Banerjee \& Duflo, } 2000 \\
\text { Gulati, } 1995 \\
\text { Kalnins \& Mayer, } 2004 \\
\text { Robinson \& Stuart, } 2007\end{array}$ & $\begin{array}{l}\text {-..pprompt renegotiation among } \\
\text { partners due to new or } \\
\text { intensified incentive } \\
\text { misalignment } \\
\text { Hamel, } 1991 \\
\text { Khanna, Gulati, \& Nohria, } 1998 \\
\text { Reuer \& Arino, 2002 } \\
\text { Reuer, Zollo, \& Singh, } 2002 \\
\text { •...prompt renegotiation among } \\
\text { partners due to changing } \\
\text { relational commitments } \\
\text { Arino \& de la Torre, } 1998 \\
\text { Doz, 1996 } \\
\text { Faems et al., 2008 } \\
\text { Ring \& Van de Ven, } 1994 \\
\text { Uzzi, } 1997\end{array}$ \\
\hline $\begin{array}{l}\text { Coordination } \\
\text { perspective }\end{array}$ & $\begin{array}{l}\text {... based on partner's coordination- } \\
\text { related experience } \\
\text { Gulati, } 1999 \\
\text {-...based on prior partnering experience }\end{array}$ & $\begin{array}{l}\text { •... relies on formal governance } \\
\text { structures and/or detailed contracts } \\
\text { to address coordination } \\
\text { requirements } \\
\text { Gulati \& Singh, } 1998\end{array}$ & $\begin{array}{l}\text {-..pprompt reorganization of } \\
\text { coordination provisions due to } \\
\text { partners' learning and } \\
\text { adaptation } \\
\text { Larson, } 1992\end{array}$ \\
\hline
\end{tabular}




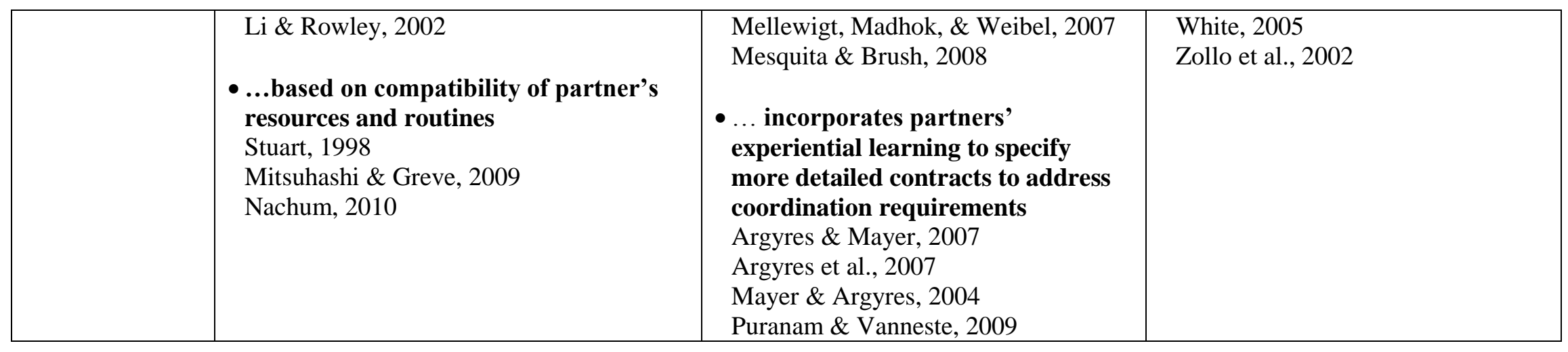

Table 2. Cooperation and coordination issues across the alliance life cycle 


\begin{tabular}{|l|l|l|}
\hline & $\begin{array}{l}\text { Relationship between } \\
\text { cooperation and coordination }\end{array}$ & $\begin{array}{l}\text { Impact of cooperation and } \\
\text { coordination on alliance } \\
\text { performance outcomes }\end{array}$ \\
\hline Independent Model & $\begin{array}{l}\text { Cooperation and coordination } \\
\text { are independent }\end{array}$ & Simple additive effect \\
\hline Interdependent Model & $\begin{array}{l}\text { Cooperation and coordination } \\
\text { are interdependent, } \\
\text { complementary, or mutually } \\
\text { reinforcing }\end{array}$ & Superadditive effect \\
\hline Interpretive Perspective & $\begin{array}{l}\text { Relationship between } \\
\text { cooperation and coordination } \\
\text { is subjectively construed; } \\
\text { possible reductionist bias }\end{array}$ & $\begin{array}{l}\text { Subjective attribution of } \\
\text { performance outcomes to } \\
\text { cooperation and coordination }\end{array}$ \\
\hline
\end{tabular}

Table 3. Alternative conceptions of the relationship between cooperation, coordination, and performance outcomes 


\section{REFERENCES}

Agarwal, R., Croson, R., \& Mahoney, J. T. 2010. The role of incentives and communication in strategic alliances: An experimental investigation. Strategic Management Journal, 31(4): 413-437.

Ahmadjian, C., \& Oxley, J. 2006. Using hostages to support exchange: Dependence balancing and partial equity stakes in japanese automotive supply relationships. Journal of Law Economics \& Organization, 22(1): 213-233.

Ahuja, G. 2000. The duality of collaboration: Inducements and opportunities in the formation of interfirm linkages. Strategic Management Journal, 21(3): 317343.

Aiken, M., Dewar, R., DiTomaso, N., Hage, J., \& Zeitz, G. 1975. Coordinating human services: New strategies for building service delivery systems. San Francisco: Jossey-Bass.

Alter, C., \& Hage, J. 1993. Organizations working together: Coordination in interorganizational networks. Newbury Park, CA: Sage.

Ancona, D. G., \& Caldwell, D. F. 1992. Bridging the boundary: External activity and performance in organizational teams. Administrative Science Quarterly, 37 634-665.

Arend, R. J., \& Seale, D. A. 2005. Modeling alliance activity: An iterated prisoners' dilemma with exit option. Strategic Management Journal, 26(11): 10571074.

Argote, L. 1982. Input uncertainty and organizational coordination in hospital emergency units. Administrative Science Quarterly, 27(3): 420-434.

Argyres, N., \& Mayer, K. J. 2007. Contract design as a firm capability: An integration of learning and transaction cost perspectives. Academy of Management Review, 32(4): 1060-1077.

Argyres, N. S., Bercovitz, J., \& Mayer, K. J. 2007. Complementarity and evolution of contractual provisions: An empirical study of IT services contracts. Organization Science, 18(1): 3-19.

Arino, A., \& de la Torre, J. 1998. Learning from failure: Towards an evolutionary model of collaborative ventures. Organization Science, 9(3): 306-325.

Axelrod, R. 1984. The Evolution of Cooperation. New York: Basic Books.

Bachmann, R. 2001. Trust, power and control in trans-organizational relations. Organization Studies, 22(2): 337-365.

Bamford, J., Gomes-Casseres, B., \& Robinson, M. 2004. Envisioning Collaboration: Mastering Alliance Strategies. San Francisco, CA: Jossey-Bass.

Banerjee, A. V., \& Duflo, E. 2000. Reputation effects and the limits of contracting: A study of the Indian software industry. Quarterly Journal of Economics, 115(3): 989-1017.

Barnard, C. I. 1938. The Functions of the Executive. Cambridge, MA: Harvard University Press.

Barney, J. B., \& Hansen, M. H. 1994. Trustworthiness as a source of competitive advantage. Strategic Management Journal, 15: 175-175. 
Baum, J. A. C., Cowan, R., \& Jonard, N. 2010. Network-independent partner selection and the evolution of innovation networks. Management Science, 56(11): 2094-2110.

Bechky, B. A. 2003. Sharing meaning across occupational communities: The transformation of understanding on a production floor. Organization Science, 14(3): 312-330.

Becker, G. S., \& Murphy, K. M. 1992. The division of labor, coordination costs and knowledge. Quarterly Journal of Economics, 107(4): 1137-1160.

Bensaou, M., \& Venkatraman, N. 1995. Configurations of interorganizational relationships: A comparison between US and Japanese automakers. Management Science, 41(9): 1471-1492.

Berends, H., Garud, R., Debackere, K., \& Weggeman, M. 2011. Thinking along: a process for tapping into knowledge across boundaries. International Journal of Technology Management, 53(1): 69-88.

Burns, T., \& Stalker, G. M. 1961. The Management of Innovation. London: Tavistock.

Cable, D. M., \& Shane, S. 1997. A prisoner's dilemma approach to entrepreneurventure capitalist relationships. Academy of Management Review, 22(1): 142-176.

Camerer, C. 2003. Behavioral Game Theory: Experiments in Strategic Interaction. Princeton, NJ: Princeton University Press.

Carson, S. J., Madhok, A., \& Wu, T. 2006. Uncertainty, opportunism, and governance: The effects of volatility and ambiguity on formal and relational contracting. Academy of Management Journal, 49(5): 1058-1077.

Casciaro, T., \& Lobo, M. S. 2008. When Competence Is Irrelevant: The Role of Interpersonal Affect in Task-Related Ties. Administrative Science Quarterly, 53(4): 655-684.

Chandler, A. 1962. Strategy and Structure: Chapters in the History of the American Industrial Enterprise. Cambridge, MA: M.I.T. Press.

Chung, S., Singh, H., \& Lee, K. 2000. Complementarity, status similarity and social capital as drivers of alliance formation. Strategic Management Journal, 21(1): 1-22.

Chwe, M. 2001. Rational Ritual: Culture, Coordination, and Common Knowledge Princeton, NJ: Princeton University Press.

Clark, K. B., \& Fujimoto, T. 1991. Product Development Performance: Strategy, Organization, and Management in the World Auto Industry. Boston, MA: Harvard Business Review Press.

Coleman, J. S. 1988. Social capital in the creation of human capital. American Journal of Sociology, 94: S95-S120.

Cooper, D. J., Hinings, B., Greenwood, R., \& Brown, J. L. 1996. Sedimentation and transformation in organizational change: The case of Canadian law firms. Organization Studies, 17(4): 623-647.

Cooper, D. J., Rose, T., Greenwood, R., \& Hinings, B. 2000. History and contingency in international accounting firms. In Y. Aharoni, \& L. Nachum (Eds.), Globalization of Services: Some Implications for Theory and Practice, Vol. 19: 93-124. 
Cooper, R. 1998. Coordination Games. Cambridge: Cambridge University Press.

Corts, K. S., \& Singh, J. 2004. The effect of repeated interaction on contract choice: Evidence from offshore drilling. Journal of Law Economics \& Organization, 20(1): 230-260.

Crocker, K. J., \& Reynolds, K. J. 1993. The efficiency of incomplete contracts: An empirical analysis of Air Force engine procurement Rand Journal of Economics, 24(1): 126-146.

Daft, R. L., \& Weick, K. E. 1984. Toward a Model of Organizations as Interpretation Systems. The Academy of Management Review, 9(2): 284-295.

Das, T. K., \& Teng, B. S. 1998. Between trust and control: Developing confidence in partner cooperation in alliances. Academy of Management Review, 23(3): 491-512.

Das, T. K., \& Teng, B. S. 2000. A resource-based theory of strategic alliances. Journal of Management, 26(1): 31-61.

Das, T. K., \& Teng, B. S. 2001. Trust, control, and risk in strategic alliances: An integrated framework. Organization Studies, 22(2): 251-283.

Das, T. K., \& Teng, S. B. 1996. Risk types and inter-firm alliance structures. Journal of Management Studies, 33(6): 827-843.

de Rond, M., \& Bouchikhi, H. 2004. On the dialectics of strategic alliances. Organization Science, 15(1): 56-69.

Deeds, D. L., \& Hill, C. W. L. 1999. An examination of opportunistic action within research alliances:: Evidence from the biotechnology industry. Journal of Business Venturing, 14(2): 141-163.

DiMaggio, P. 1997. Culture and Cognition. Annual Review of Sociology, 23: 262-287.

Dosi, G., Levinthal, D. A., \& Marengo, L. 2003. Bridging contested terrain: linking incentive-based and learning perspectives on organizational evolution. Industrial and Corporate Change, 12(2): 413-436.

Doz, Y. L. 1996. The evolution of cooperation in strategic alliances: Initial conditions or learning processes? Strategic Management Journal, 17: 55-83.

Doz, Y. L., \& Hamel, G. 1998. Alliance Advantage: The Art of Creating Value Through Partnering. Boston, MA: Harvard Business School Press.

Dyer, J. H. 1996. Does governance matter? Keiretsu alliances and asset specificity as sources of Japanese competitive advantage. Organization Science, 7(6): 649666.

Dyer, J. H. 1997. Effective interfirm collaboration: How firms minimize transaction costs and maximize transaction value. Strategic Management Journal, 18(7): 535-556.

Dyer, J. H., Kale, P., \& Singh, H. 2001. How to make strategic alliances work. Mit Sloan Management Review, 42(4): 37-43.

Dyer, J. H., \& Singh, H. 1998. The relational view: Cooperative strategy and sources of interorganizational competitive advantage. Academy of Management Review, 23(4): 660-679.

Eberly, M. B., Holley, E. C., Johnson, M. D., \& Mitchell, T. R. 2011. Beyond internal and external: A dyadic theory of relational attribution. Academy of Management Review, 36(4): 731-753. 
Eisenhardt, K. M., \& Schoonhoven, C. B. 1996. Resource-based view of strategic alliance formation: Strategic and social effects in entrepreneurial firms. Organization Science, 7(2): 136-150.

Faems, D., Janssens, M., Madhok, A., \& Van Looy, B. 2008. Toward an integrative perspective on alliance governance: Connecting contract design, trust dynamics and contract application Academy of Management Journal, 51(6): 1053-1078.

Fayol, H. 1949. General and Industrial Management. London: Pitman Publishing Company.

Follett, M. P. 1949. Freedom \& Co-ordination: Lectures in Business Organization (1987 reprint ed.). New York: Management Publications Trust.

Folta, T. B., \& Miller, K. D. 2002. Real options in equity partnerships. Strategic Management Journal, 23(1): 77-88.

Galbraith, J. R. 1977. Organization Design. Reading, MA: Addison-Wesley.

Gerwin, D. 2004. Coordinating New Product Development in Strategic Alliances. The Academy of Management Review, 29(2): 241-257.

Gerwin, D., \& Ferris, J. S. 2004. Organizing new product development projects in strategic alliances. ORGANIZATION SCIENCE, 15(1): 22-37.

Ghoshal, S., \& Moran, P. 1996. Bad for practice: A critique of the transaction cost theory. Academy of Management Review, 21(1): 13-47.

Gittell, J. H. 2002. Coordinating mechanisms in care provider groups: Relational coordination as a mediator and input uncertainty as a moderator of performance effects. Management Science: 1408-1426.

Goerzen, A. 2007. Alliance networks and firm performance: The impact of repeated partnerships. Strategic Management Journal, 28(5): 487-509.

Grandori, A., \& Soda, G. 1995. Interfirm networks: Antecedents, mechanisms and forms. Organization Studies, 16(2): 183-214.

Gulati, R. 1995a. Does familiarity breed trust? The implications of repeated ties for contractual choice in alliances. Academy of Management Journal, 38(1): 85112.

Gulati, R. 1995b. Social structure and alliance formation patterns: A longitudinal analysis. Administrative Science Quarterly, 40(4): 619-652.

Gulati, R. 1998. Alliances and networks. Strategic Management Journal, 19(4): 293-317.

Gulati, R. 1999. Network location and learning: The influence of network resources and firm capabilities on alliance formation. Strategic Management Journal, 20(5): 397-420.

Gulati, R. 2007a. Managing Network Resources: Alliances, Affiliations And Other Relational Assets Oxford: Oxford University Press.

Gulati, R. 2007b. Silo busting - How to execute on the promise of customer focus. Harvard Business Review, 85(5): 98-+.

Gulati, R. 2010. Reorganize for Resilience: Putting Customers at the Center of Your Organization: Harvard Business School Press.

Gulati, R., \& Gargiulo, M. 1999. Where do interorganizational networks come from? American Journal of Sociology, 104(5): 1439-1493. 
Gulati, R., Khanna, T., \& Nohria, N. 1994. Unilateral commitments and the importance of process in alliances. Sloan Management Review, 35(3): 6169.

Gulati, R., Lavie, D., \& Singh, H. 2009. The nature of partnering experience and the gains from alliance. Strategic Management Journal, 30(11): 1213-1233.

Gulati, R., Lawrence, P. R., \& Puranam, P. 2005. Adaptation in vertical relationships: Beyond incentive conflict. Strategic Management Journal, 26(5): 415-440.

Gulati, R., Raveendran, M., \& Silvestri, L. 2012. Differentiation, Coordination, and Integration under Knowledge Interdependence. Working Paper.

Gulati, R., \& Singh, H. 1998. The architecture of cooperation: Managing coordination costs and appropriation concerns in strategic alliances. Administrative Science Quarterly, 43(4): 781-814.

Gulati, R., \& Sytch, M. 2007. Dependence asymmetry and joint dependence in interorganizational relationships: Effects of embeddedness on a manufacturer's performance in procurement relationships. Administrative Science Quarterly, 52(1): 32-69.

Gulati, R., \& Sytch, M. 2008. Does familiarity breed trust? Revisiting the antecedents of trust. Managerial and Decision Economics, 29: 165-195.

Gulati, R., Sytch, M., \& Mehrotra, P. 2008. Breaking up is never easy: Planning for exit in a strategic alliance. California Management Review, 50(4): 147-163.

Guler, I. 2007. Throwing good money after bad? Political and institutional influences on sequential decision making in the venture capital industry. Administrative Science Quarterly, 52(2): 248-285.

Guler, I., \& Guillen, M. F. 2010. Home country networks and foreign expansion: Evidence from the venture capital industry. Academy of Management Journal, 53(2): 390-410.

Gulick, L., \& Urwick, L. (Eds.). 1937. Papers on the Sience of Administration. New York: Institute of Public Adminstration, Columbia University.

Hamel, G. 1991. Competition for competence and inter-partner learning within international strategic alliances Strategic Management Journal, 12: 83-103.

Hannan, M. T., \& Freeman, J. 1984. Structural inertia and organizational change. American Sociological Review, 49(2): 149-164.

Hansen, M. T. 1999. The Search-Transfer Problem: The Role of Weak Ties in Sharing Knowledge across Organization Subunits. Administrative Science Quarterly, 44(1): 82-111.

Heath, C., \& Staudenmayer, N. 2000. Coordination neglect: How lay theories of organizing complicate coordination in organizations. Research in Organizational Behavior, Vol 22, 2000, 22: 153-191.

Heide, J. B., \& Miner, A. S. 1992. The shadow of the future: Effects of anticipated interaction and frequency of contact on buyer-seller cooperation Academy of Management Journal, 35(2): 265-291.

Hennart, J. F. 1988. A transaction costs theory of equity joint ventures. Strategic Management Journal, 9(4): 361-374.

Hewstone, M. 1990. The ultimate attribution error: A review of the literature on intergroup causal attribution. European Journal of Social Psychology, 20(4): 311-335. 
Hoang, H., \& Rothaermel, F. T. 2005. The effect of general and partner-specific alliance experience on joint R\&D project performance. Academy of Management Journal, 48(2): 332-345.

Ingram, P., \& Inman, C. 1996. Institutions, intergroup competition, and the evolution of hotel populations around Niagara Falls. Administrative Science Quarterly, 41(4): 629-658.

Ingram, P., \& McEvily, B. 2007. Sharper in relief: Opposition, identity and the maintenance of social movement organizations. New York: Columbia University Working Paper.

Ingram, P., \& Yue, L. Q. 2008. Structure, affect and identity as bases of organizational competition and cooperation. Academy of Management Annals, 2: 275-303.

Inkpen, A. C., \& Beamish, P. W. 1997. Knowledge, bargaining power, and the instability of international joint ventures. Academy of Management Review, 22(1): 177-202.

Kale, P., Dyer, J. H., \& Singh, H. 2002. Alliance capability, stock market response, and long-term alliance success: The role of the alliance function. Strategic Management Journal, 23(8): 747-767.

Kale, P., \& Singh, H. 2009. Managing strategic alliances: What do we know now, and where do we go from here? Academy of Management Perspectives, 23(3): 45-62.

Kale, P., Singh, H., \& Perlmutter, H. 2000. Learning and protection of proprietary assets in strategic alliances: Building relational capital. Strategic Management Journal, 21(3): 217-237.

Kalnins, A., \& Mayer, K. J. 2004. Relationships and hybrid contracts: An analysis of contract choice in information technology. Journal of Law Economics \& Organization, 20(1): 207-229.

Kerr, N. L. 1983. Motivation losses in small groups: A social dilemma analysis. Journal of Personality and Social Psychology, 45(4): 819-828.

Khanna, T., Gulati, R., \& Nohria, N. 1998. The dynamics of learning alliances: Competition, cooperation, and relative scope. Strategic Management Journal, 19(3): 193-210.

Killing, J. P. 1983. Strategies for joint venture success. New York, NY: Praeger.

Klein, B. 1996. Why hold-ups occur: The self-enforcing range of contractual relationships. Economic Inquiry, 34(3): 444-463.

Knez, M., \& Camerer, C. 1994. Creating expectational assets in the laboratory: Coordination in weakest-link games. Strategic Management Journal, 15: 101-119.

Kogut, B. 1988. Joint ventures: Theoretical and empirical perspectives. Strategic Management Journal, 9(4): 319-332.

Kogut, B. 2000. The network as knowledge: Generative rules and the emergence of structure. Strategic Management Journal, 21(3): 405-425.

Kogut, B., \& Zander, U. 1996. What firms do? Coordination, identity, and learning. Organization Science, 7(5): 502-518.

Koka, B. R., Madhavan, R., \& Prescott, J. E. 2006. The evolution of interfirm networks: Environmental effects on patterns of network change. Academy of Management Review, 31(3): 721-737. 
Koza, M. P., \& Lewin, A. Y. 1998. The co-evolution of strategic alliances. Organization Science, 9(3): 255-264.

Kretschmer, T., \& Puranam, P. 2008. Integration through incentives within differentiated organizations. Organization Science, 19(6): 860-875.

Larson, A. 1992. Network dyads in entrepreneurial settings: A study of the governance of exchange relations. Administrative Science Quarterly, 37(1): 76-104.

Larsson, R., Bengtsson, L., Henriksson, K., \& Sparks, J. 1998. The interorganizational learning dilemma: Collective knowledge development in strategic alliances. Organization Science, 9(3): 285-305.

Lawler, E. J., Thye, S. R., \& Yoon, J. 2000. Emotion and group cohesion in productive exchange. American Journal of Sociology, 106(3): 616-657.

Lawrence, P. R., \& Lorsch, J. W. 1967. Organization and Environment: Managing Differentiation and Integration. Boston, MA: Harvard University Press.

Levitt, B., \& March, J. G. 1988. Organizational learning. Annual Review of Sociology, 14: 319-340.

Li, S. X., \& Rowley, T. J. 2002. Inertia and evaluation mechanisms in interorganizational partner selection: Syndicate formation among US investment banks. Academy of Management Journal, 45(6): 1104-1119.

Litwak, E., \& Hylton, L. F. 1962. Interorganizational Analysis: A hypothesis on coordinating agencies. Administrative Science Quarterly, 6(4): 395-420.

Lunnan, R., \& Haugland, S. A. 2008. Predicting and measuring alliance performance: A multidimensional analysis. Strategic Management Journal, 29(5): 545556.

Luo, Y. 2006. Opportunism in cooperative alliances: Conditions and solutions. In 0. Shenkar, \& J. J. Reuer (Eds.), Handbook of strategic alliances: 55-80. Thousand Oaks, CA: Sage.

Luo, Y. D. 2002. Contract, cooperation, and performance in international joint ventures. Strategic Management Journal, 23(10): 903-919.

Luo, Y. D. 2005. How important are shared perceptions of procedural justice in cooperative alliances? Academy of Management Journal, 48(4): 695-709.

Macaulay, S. 1963. Non-contractual relations in business: A preliminary study. American Sociological Review, 28(1): 55-67.

Madhavan, R., Koka, B. R., \& Prescott, J. E. 1998. Networks in transition: How industry events (re)shape interfirm relationships. Strategic Management Journal, 19(5): 439-459.

Malhotra, D., \& Murnighan, J. K. 2002. The effects of contracts on interpersonal trust. Administrative Science Quarterly, 47(3): 534-559.

Mayer, K. J., \& Argyres, N. S. 2004. Learning to contract: Evidence from the personal computer industry. Organization Science, 15(4): 394-410.

Mayer, R. C., Davis, J. H., \& Schoorman, F. D. 1995. An integrative model of organizational trust. Academy of Management Review, 20(3): 709-734.

McEvily, B., Perrone, V., \& Zaheer, A. 2003. Trust as an organizing principle. Organization Science, 14(1): 91-103. 
Mellewigt, T., Madhok, A., \& Weibel, A. 2007. Trust and formal contracts in interorganizational relationships - substitutes and complements. Managerial and Decision Economics, 28: 833-847.

Mesquita, L. F., \& Brush, T. H. 2008. Untangling safeguard and production coordination effects in long-term buyer-supplier relationships. Academy of Management Journal, 51(4): 785-807.

Meuleman, M., Lockett, A., Manigart, S., \& Wright, M. 2010. Partner Selection Decisions in Interfirm Collaborations: The Paradox of Relational Embeddedness. Journal of Management Studies, 47(6): 995-1019.

Mishina, Y., Pollock, T. G., \& Porac, J. F. 2004. Are more resources always better for growth? Resource stickiness in market and product expansion. Strategic Management Journal, 25(12): 1179-1197.

Mitsuhashi, H., \& Greve, H. R. 2009. A matching theory of alliance formation and organizational success: Complementarity and compatibility. Academy of Management Journal, 52(5): 975-995.

Mohr, J., \& Spekman, R. 1994. Characteristics of partnership success: Partnership attributes, communication behavior, and conflict-resolution techniques. Strategic Management Journal, 15(2): 135-152.

Molm, L. D., Takahashi, N., \& Peterson, G. 2000. Risk and trust in social exchange: An experimental test of a classical proposition. American Journal of Sociology, 105(5): 1396-1427.

Nachum, L. 2010. Foreignness, multinationality and inter-organizational relationships. Strategic Organization, 8(3): 230-254.

Nickerson, R. S. 1998. Confirmation bias: A ubiquitous phenomenon in many guises. Review of General Psychology; Review of General Psychology, 2(2): 175.

Nisbett, R. E., \& Ross, L. 1980. Human inference: Strategies and shortcomings of social judgment. Englewood Cliffs, NJ: Prentice-Hall.

Noteboom, B. 1999. Inter-firm alliances: Analysis and design. New York: Routledge.

Ocasio, W. 1997. Towards an attention-based view of the firm. Strategic Management Journal, 18: 187-206.

Okhuysen, G. A., \& Bechky, B. A. 2009. Coordination in Organizations: An Integrative Perspective. Academy of Management Annals, 3: 463-502.

Oliver, C. 1990. Determinants of interorganizational relationships: Integration and future directions. Academy of Management Review, 15(2): 241-265.

Oxley, J., \& Wada, T. 2009. Alliance Structure and the Scope of Knowledge Transfer: Evidence from US-Japan Agreements. Management Science, 55(4): 635-649.

Oxley, J. E. 1997. Appropriability hazards and governance in strategic alliances: A transaction cost approach. Journal of Law Economics \& Organization, 13(2): 387-409.

Oxley, J. E., \& Sampson, R. C. 2004. The scope and governance of international R\&D alliances. Strategic Management Journal, 25(8-9): 723-749.

Palmer, D. 1983. Broken ties: Interlocking directorates and intercorporate coordination. Administrative Science Quarterly: 40-55. 
Park, S. H., \& Ungson, G. R. 2001. Interfirm rivalry and managerial complexity: A conceptual framework of alliance failure. Organization Science, 12(1): 3753.

Parkhe, A. 1993. Strategic alliance structuring: A game-theoretic and transaction cost examination of interfirm cooperation. Academy of Management Journal, 36(4): 794-829.

Penrose, E. 1959. The Theory ofthe Growth of the Firm. Oxford, UK: Oxford University Press.

Pfeffer, J., \& Nowak, P. 1976. Joint ventures and interorganizational interdependence. Administrative Science Quarterly, 21(3): 398-418.

Pfeffer, J., \& Salancik, G. R. 1978. The External Control of Organizations: A Resource Dependency Perspective. New York: Harper \& Row.

Phillips, A. 1960. A theory of inter-firm organization. Quarterly Journal of Economics, 74: 602-613.

Phillips, D. J., Turco, C., \& Zuckerman, E. 2011. High-status conformity and deviance: Pressures for purity among U.S. corporate law firms. Cambridge, MA: MIT Sloan School of Management Working Paper.

Pisano, G. P. 1989. Using equity participation to support exchange: Evidence from the biotechnology industry Journal of Law Economics \& Organization, 5(1): 109-126.

Podolny, J. M. 1994. Market uncertainty and the social character of economic exchange. Administrative Science Quarterly, 39(3): 458-483.

Poppo, L., \& Zenger, T. 2002. Do formal contracts and relational governance function as substitutes or complements? Strategic Management Journal, 23(8): 707725.

Poppo, L., Zhou, K. Z., \& Ryu, S. M. 2008. Alternative origins to interorganizational trust: An interdependence perspective on the shadow of the past and the shadow of the future. Organization Science, 19(1): 39-55.

Powell, W. W. 1990. Neither market nor hierarchy: Network forms of organization. Research in Organizational Behavior 12: 295-336.

Provan, K. G., \& Milward, H. B. 1995. A Preliminary Theory of Interorganizational Network Effectiveness: A Comparative Study of Four Community Mental Health Systems. Administrative Science Quarterly, 40(1): 1-33.

Puranam, P., Raveendran, M., \& Knudsen, T. 2012. Organization design: The epistemic interdependence perspective. Academy of Management Review, Forthcoming.

Puranam, P., Singh, H., \& Chaudhuri, S. 2009. Integrating acquired capabilities: When structural integration is (un)necessary. Organization Science, 20(2): 313328.

Puranam, P., \& Vanneste, B. S. 2009. Trust and governance: Untangling a tangled web. Academy of Management Review, 34(1): 11-31.

Raveendran, M., \& Puranam, P. 2012. Interdependence and Organization Design. In A. Grandori (Ed.), Handbook of Economic Organization: Forthcoming.

Raveendran, M., Puranam, P., \& Warglien, M. 2012. The emergence of the division of labor: A qualitative lab study. London, UK: London Business School Working Paper. 
Reich, R. B., \& Mankin, E. D. 1986. Joint ventures with Japan give away our future. Harvard Business Review, 64(2): 78-86.

Reuer, J. J., \& Arino, A. 2002. Contractual renegotiations in strategic alliances. Journal of Management, 28(1): 47-68.

Reuer, J. J., \& Arino, A. 2007. Strategic alliance contracts: Dimensions and determinants of contractual complexity. Strategic Management Journal, 28(3): 313-330.

Reuer, J. J., \& Tong, T. W. 2005. Real options in international joint ventures. Journal of Management, 31(3): 403-423.

Reuer, J. J., Zollo, M., \& Singh, H. 2002. Post-formation dynamics in strategic alliances. Strategic Management Journal, 23(2): 135-151.

Ring, P. S., \& Van de Ven, A. H. 1992. Structuring cooperative relationships between organizations. Strategic Management Journal, 13(7): 483-498.

Ring, P. S., \& Van de Ven, A. H. 1994. Developmental processes of cooperative interorganizational relationships. Academy of Management Review, 19(1): 90-118.

Robinson, D. T., \& Stuart, T. E. 2007. Network effects in the governance of strategic alliances. Journal of Law Economics \& Organization, 23(1): 242-273.

Rogers, D. L., \& Whetten, D. 1982. Interorganizational Coordination: Theory, Research, and Implementation. Ames, IO: Iowa State University Press.

Ross, L. 1977. The intuitive psychologist and his shortcomings: Distortions in the attribution process. In L. Berkowitz (Ed.), Advances in Experimental Social Psychology, Vol. 10. New York: Academic Press.

Sampson, R. C. 2004. The cost of misaligned governance in R\&D alliances. Journal of Law Economics \& Organization, 20(2): 484-526.

Schnake, M. E. 1991. Equity in effort: The sucker effect in co-acting groups. Journal of Management, 17(1): 41-55.

Schoorman, F. D., Mayer, R. C., \& Davis, J. H. 1996. Organizational trust: Philosophical perspectives and conceptual definitions. Academy of Management Review, 21(2): 337-340.

Schoorman, F. D., Mayer, R. C., \& Davis, J. H. 2007. An integrative model of organizational trust: Past, present, and future. Academy of Management Review, 32(2): 344-354.

Schreiner, M., Kale, P., \& Corsten, D. 2009. What really is alliance management capability and how does it impact alliance outcomes and success? Strategic Management Journal, 30(13): 1395-1419.

Seabright, M. A., Levinthal, D. A., \& Fichman, M. 1992. Role of individual attachments in the dissolution of interorganizational relationships. Academy of Management Journal, 35(1): 122-160.

Selznick, P. 1957. Leadership in Administration. New York: Harper Row.

Seth, A., \& Chi, T. 2006. What does a real options perspective add to the understanding of strategic alliances? In O. Shenkar, \& J. J. Reuer (Eds.), Handbook of strategic alliances: 101-116. Thousand Oaks, CA: Sage.

Simon, H. A., \& March, J. G. 1993. Organizations Cambridge, MA: Blackwell Business. Smith, A. [1776] 1979. The Wealth of Nations. Baltimore: Penguin Press. 
Smith, K. G., Carroll, S. J., \& Ashford, S. J. 1995. Intra- and inter-organizational cooperation: toward a research agenda. Academy of Management Journal, $38(7-23)$.

Sorenson, O., \& Stuart, T. E. 2008. Bringing the context back in: Settings and the search for syndicate partners in venture capital investment networks. Administrative Science Quarterly, 53(2): 266-294.

Steensma, H. K., Marino, L., Weaver, K. M., \& Dickson, P. H. 2000. The Influence of National Culture on the Formation of Technology Alliances by Entrepreneurial Firms. The Academy of Management Journal, 43(5): 951973.

Stinchcombe, A. 1985. Contracts as hierarchical documents. In A. L. Stinchcombe, \& C. A. Heimer (Eds.), Organization Theory and Project Management: Administering Uncertainty in Norwegian Offshore Oil: Norwegian University Press.

Stuart, T. E. 1998. Network positions and propensities to collaborate: An investigation of strategic alliance formation in a high-technology industry. Administrative Science Quarterly, 43(3): 668-698.

Sugden, R. 1995. A theory of focal points. The Economic Journal: 533-550.

Szulanski. 2003. Sticky Knowledge: Barriers to the Knowing Firm. Thousand Oaks, CA: Sage.

Thomas, J. B., \& Trevino, L. K. 1993. Information processing in strategic alliance building: A multiple-case approach. Journal of Management Studies, 30(5): 779-814.

Thompson, J. D. 1967. Organizations in Action: Social Science Bases of Administrative Theory. New York: McGraw-Hill.

Tilcsik, A. 2010. From ritual to reality: Demography, ideology, and decoupling in a post-communist government agency. Academy of Management Journal, 53(6): 1474-1498.

Trapido, D. 2007. Competitive embeddedness and the emergence of interfirm cooperation. Social Forces, 86(1): 165-191.

Tuomela, R. 2000. Cooperation: A philosophical study. Dordrecht, Netherlands: Kluwer Academic.

Tushman, M. L., \& Nadler, D. A. 1978. Information processing as an integrating concept in organizational design. Academy of Management Review: 613624.

Uzzi, B. 1997. Social structure and competition in interfirm networks: The paradox of embeddedness. Administrative Science Quarterly, 42(1): 35-67.

Uzzi, B. 1999. Embeddedness in the Making of Financial Capital: How Social Relations and Networks Benefit Firms Seeking Financing. American Sociological Review, 64(4): 481-505.

Van de Ven, A. H., Delbecq, A. L., \& Koenig, R. 1976. Determinants of coordination modes within organizations. American Sociological Review, 41(2): 322-338.

Van de Ven, A. H., \& Walker, G. 1984. The dynamics of interorganizational coordination. Administrative Science Quarterly, 29(4): 598-621. 
Van Huyck, J. B., Battalio, R. C., \& Rankin, F. W. 1997. On the origin of convention: Evidence from coordination games. The Economic Journal, 107(442): 576596.

Vanneste, B. S., \& Puranam, P. 2010. Repeated interactions and contractual detail: Identifying the learning effect. Organization Science, 21(1): 186-201.

Varshney, L. R., \& Oppenheim, D. V. 2011. On Cross-Enterprise Collaboration. In S. Rinderle-Ma, F. Toumani, \& K. Wolf (Eds.), Business Process Management, Vol. 6896: 29-37: Springer Berlin / Heidelberg.

Vlaar, P. W. L., Van den Bosch, F. A. J., \& Volberda, H. W. 2006. Coping with problems of understanding in interorganizational relationships: Using formalization as a means to make sense. Organization Studies, 27(11): 1617-1638.

Walker, G., Kogut, B., \& Shan, W. J. 1997. Social capital, structural holes and the formation of an industry network. Organization Science, 8(2): 109-125.

Weber, M. 1974. From Max Weber: Essays in Sociology. Trans. \& Ed. H. H. Gerth \& C. Wright Mills. London: Routledge \& Kegan Paul.

Weiner, B. 1985. An attributional theory of achievement motivation and emotion. Psychological Review, 92: 548-573.

White, S. 2005. Cooperation costs, governance choice and alliance evolution. Journal of Management Studies, 42(7): 1383-1412.

White, S., \& Lui, S. S. Y. 2005. Distinguishing costs of cooperation and control in alliances. Strategic Management Journal, 26(10): 913-932.

Williamson, O. E. 1983. Credible commitments: Using hostages to support exchange. American Economic Review, 73(4): 519-540.

Williamson, O. E. 1985. The Economic Institutions of Capitalism : Firms, Markets, Relational Contracting. New York and London: Free Press and Collier Macmillan.

Williamson, O. E. 1991. Comparative Economic Organization: The Analysis of Discrete Structural Alternatives. Administrative Science Quarterly, 36(2): 269-296.

Young, H. P. 1993. The evolution of conventions. Econometrica: Journal of the Econometric Society: 57-84.

Zaheer, A., McEvily, B., \& Perrone, V. 1998. Does trust matter? Exploring the effects of interorganizational and interpersonal trust on performance. Organization Science, 9(2): 141-159.

Zeng, M., \& Chen, X. P. 2003. Achieving cooperation in multiparty alliances: A social dilemma approach to partnership management. Academy of Management Review, 28(4): 587-605.

Zollo, M., \& Reuer, J. J. 2010. Experience spillovers across corporate development activities. Organization Science, 21(6): 1195-1212.

Zollo, M., Reuer, J. J., \& Singh, H. 2002. Interorganizational routines and performance in strategic alliances. Organization Science, 13(6): 701-713. 
